\title{
Workers under Communist Rule: Research in the Former Socialist Countries of Eastern-Central and South-Eastern Europe and in the Federal Republic of Germany
}

\author{
PETER HEUMOS \\ Independent Scholar in Mid-and Eastern European History, \\ Moosburg \\ E-mail: janaheumos@yahoo.de
}

Summary: After the collapse of the communist system in eastern Europe, the development of the historiographies in the Czech and Slovak republics, Poland, Hungary, Romania, Bulgaria, and the Federal Republic of Germany has been characterized by a broad spectrum of differences. This article offers an overview of the ways in which these differences have worked out for the history of the working class in the eastern European countries under communist rule, understood here as the social history of workers. It shows that cultural and political traditions and the "embedding" of historical research in the respective societies prior to 1989 , the extent to which historiography after 1989 was able to connect to pre-I989 socialhistorical or sociological investigations, and the specific national political situation after 1989 make up for much of the differences in the ways that the history of the working class is dealt with in the countries concerned.

Since the collapse of the communist system in eastern Europe, the historiographies of the different countries of the former Soviet bloc have taken different paths. ${ }^{\mathrm{I}}$ Two things appeared initially at least to speak for a common point of departure: the significant change of personnel and the

I. For an overview of the historiographical development in eastern Europe after the fall of communism, see Alojz Ivanišević et al. (eds), Klio ohne Fesseln? Historiographie im östlichen Europa nach dem Zusammenbruch des Kommunismus (Münster, 2004); specifically on the development trends of working-class history, see Bruno Groppo, Quellen und Historiographie der Arbeiterbewegung nach dem Zusammenbruch des "Realsozialismus" (Vienna, 1998). 
contraints of the institutional bases of historical research, on the one hand, and the "abolition" of Marxist-Leninist historiography, on the other. However, cultural and political traditions and the "embedding" of historical research in the respective societies prior to 1989 in terms of the manoeuvring room that researchers had created for themselves vis-à-vis state socialism - all of this accounted for a broad spectrum of differences. These differences are also evident in regard to the question of how the historiographies of the Czech and Slovak Republics, Poland, Hungary, Romania, Bulgaria, and the Federal Republic of Germany have contributed after 1989 to working-class history under communist rule.

Working-class history is understood in this article as the social history of workers. ${ }^{3}$ Were the developments in historiography in eastern Europe after I989 able to connect to social-historical or sociological investigations prior to 1989? The answer to this question alone provides a colourful picture.

While it has been pointed out for Romania, for instance, that the sum of "new scholarship on the Romanian working class" is thin "because sociology was banned in the I980s as a separate discipline", ${ }^{4}$ sociology and social history in Poland and in Hungary were established at a comparatively high level long before 1989. The most recent Polish studies on everyday life in industrial plants during the communist era refer as a matter of course to sociological and social-historical works from the i960s. ${ }^{5}$ Czech and Slovak historians, in contrast, agree that social history, especially the social history of workers prior to 1989, did not produce anything they could draw upon. ${ }^{6}$ The situation is also different for the German Democratic Republic (GDR). Although unbiased West German voices affirmed that historical research in the GDR did include productive social-historical approaches prior to I $989,{ }^{7}$ these remained relevant in the appropriation process of East German

2. For the West German side on this, see Martin Sabrow, Das Diktat des Konsenses. Geschichtswissenschaft in der DDR 1949-1969 (Munich, 200I). Significantly more composed regarding Poland is Jerzy Topolski, "Polish Historians and Marxism after World War II", Studies in Soviet Thought, 43 (1992), pp. 169-183.

3. Publications on working-class history oriented around the ideology, the programme, and the political organization of workers have not been considered here - for example, the articles in the yearbook published in Budapest up to 2000: A nemzetközi munkásmozgalom történetéb [From the History of the International Workers' Movement].

4. Letter from Romanian historian Dragoş Petrescu to the author, I2 April 2009.

5. On this, see for instance the study by Małgorzata Mazurek: "Das Alltagsleben im sozialistischen Betrieb am Beispiel der 'Rosa-Luxemburg-Werke' in Warschau an der Schwelle zur 'kleinen Stabilisierung'”, in Peter Hübner, Christoph Kleßmann, and Klaus Tenfelde (eds), Arbeiter im Staatssozialismus. Ideologischer Anspruch und soziale Wirklichkeit (Cologne [etc.], 2005), pp. 29I-3I7.

6. Peter Heumos (ed.), Sozialgeschichte und soziale Bewegungen in der Historiographie der Tschechischen und der Slowakischen Republik (Bochum, 2000).

7. Jürgen Kocka, "Zur jüngeren marxistischen Sozialgeschichte. Eine kritische Analyse unter besonderer Berücksichtigung sozialgeschichtlicher Ansätze in der DDR”, in Alexander Fischer 


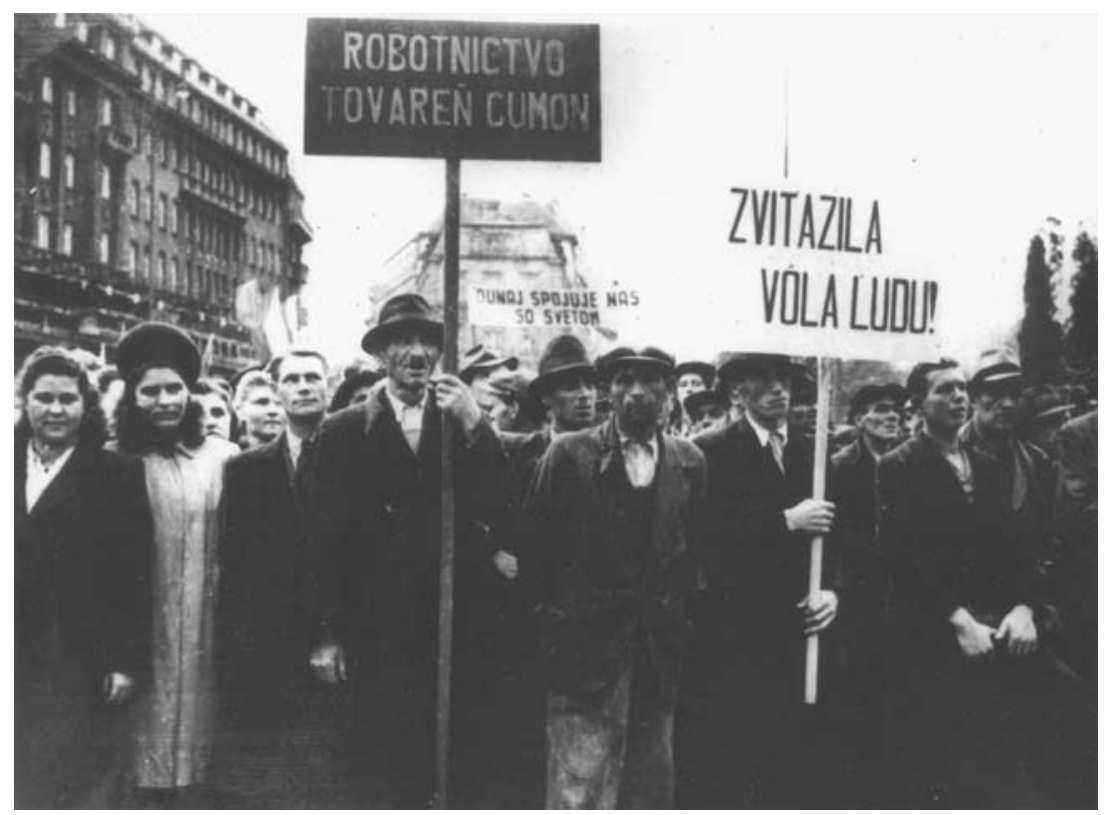

Figure I. Workers from the Cumon factories in Bratislava after the nationalization of industry in October 1945. The Slovak text on the right reads: "Victory of the People's Will!". Photograph: Private collection of the author.

historiography by West German historiography only to the extent that isolated GDR researchers were exempted from the demonstration of West German "cultural sovereignty".

The political implications of historical analyses of communist systems are particularly evident in the case of the GDR. After I989, the assumption of the GDR's "illegal character" initially unleashed an avalanche of research on the Ministry for State Security (Stasi) and the entire repressive apparatus of the SED (Sozialistische Einheitspartei Deutschlands [Socialist Unity Party of Germany]) dictatorship, which employed a rigid conception of totalitarianism. Only when a certain disillusionment emerged in the course of such investigations did the emphasis shift slightly in favour of social-historical approaches, which, however, had a bad reputation from the very start as "leftist" trivialization of the

and Günther Heydemann (eds), Geschichtswissenschaft in der DDR, I (Berlin, I988), pp. $395-422$.

8. Already in the autumn of 1997 , the Institute for Social Movements in Bochum held a conference on workers in the GDR, the results of which have more than merely provisional value from a contemporary perspective; see Peter Hübner and Klaus Tenfelde (eds), Arbeiter in $\operatorname{der} S B Z-D D R$ (Essen, 1998). 
SED state, ${ }^{9}$ and which still continue overall to represent a "minority phenomenon". In the meantime, calm has largely returned to the front between these two research trends, and both conceptions are currently practised in peaceful coexistence. ${ }^{\mathrm{IO}}$

\section{THE CZECH AND SLOVAK REPUBLICS}

After 1989 working-class history stood at the very bottom of the priority list of Czech and Slovak researchers, and even today its position has improved only marginally. Attempts to approach social history have occurred on different levels. At times studies conceived as general or political history have been "socially enriched". ${ }^{I I}$ Frequently spectacular events or ruptures in the development of the communist system have been investigated in terms of social background or social consequences - for instance, the currency reform of $1953 .{ }^{\mathrm{I} 2} \mathrm{~A}$ third variant concentrates on long-term changes in the social macrostructure of the entire society; the guiding issues here are the social and economic consequences of the Sovietization of the country following the communist assumption of power in February 1948. ${ }^{13}$ Fourth, a path to social history is also sought through an analysis of social policy and the social system. ${ }^{I 4}$ Closely

9. Thomas Lindenberger, “'Gerechte Gewalt?’ Der 17. Juni 1953 - ein weißer Fleck in der historischen Protestforschung”, in Henrik Bispinck, Jürgen Danyel, Hans-Hermann Hertle, and Hermann Wentker (eds), Aufstände im Ostblock. Zur Krisengeschichte des realen Sozialismus (Berlin, 2004), pp. I I 3-I 28.

ı. One example of the juxtaposition of political-science approaches and social-historical interpretations focusing on the "limits of dictatorship" is Roger Engelmann, Thomas Großbölting, and Hermann Wentker (eds), Kommunismus in der Krise. Die Entstalinisierung 1956 und die Folgen. Im Auftrag des Instituts für Zeitgeschichte und der Bundesbeauftragten für die Unterlagen des Staatssicherheitsdienstes der ehemaligen DDR (Göttingen, 2008).

I I. Exemplary here is Jiří Pernes, Snahy o prekonáni politicko-hospodáršké krize v Čskoslovensku v roce 1953 [The Efforts to Overcome the Political-Economic Crisis in Czechoslovakia in 1953] (Brno, 2000); for Slovakia, see Michal Barnovský, Na ceste $k$ monopolu moci. Mocenské zápasy na Slovensku v rokoch 1945-1948 [On the Path to the Monopoly of Power. Power Struggles in Slovakia between 1945 and 1948] (Bratislava, I993).

I 2. Dana Musilová, Měnová reforma 1953 a jeji sociálni drisledky. Studie a dokumenty [The Currency Reform of 1953 and its Social Consequences. Study and Documents] (Prague, 1994). I3. Lenka Kalinová, Karel Jech, Karel Kaplan, Jiří Maňák, and Václav Průcha, K proměnám socialni struktury v Ceskoslovensku 19I8-1968 [On the Changes of the Social Structure in Czechoslovakia 1918-1968] (Prague, 1993); Jaroslav Krejčí and Pavel Machonin, Czechoslovakia, 1918-1992: A Laboratory for Social Change (London, 1996).

I4. Jana Geršlová, "Vývoj sociální politiky a sociálních opatření v Československu v letech 1945-1960" [The Development of Social Policy and Social Measures in Czechoslovakia between I945 and 1960], Slezský sbornik, 88 (1990), pp. 25-35; Lenka Kalinová, Sociáln reforma a sociálni realita $v$ Československu $v$ sedesátých letech [Social Reform and Social Reality in Czechoslovakia in the 1960s] (Prague, 1998); idem, Transformace sociálniho systému v Ceskoslovensku po unoru 1948 [The Transformation of the Social System in Czechoslovakia after February 1948] (Prague, 1998). 
related to this are investigations of industrial relations issues and thereby also trade unions. ${ }^{\text {Is }}$

Whereas these kinds of works usually touch on the self-conception of social groups only through the question of whether the wage, consumption, and general social policies of the state accorded with the needs of these groups, sociological investigations of the social conditions of the Czechoslovakian population have developed a more differentiated set of methodological tools. ${ }^{16}$ Although these studies should by and large be classified as transformation research, they frequently offer significant information about all social groups, including the workforce, for the final decade of the communist era. ${ }^{17}$ Investigations focusing exclusively on the social conditions of workers continue to be rare. ${ }^{18}$

The first studies on the cultural-political and political-ideological orchestration of the working class have been published, ${ }^{19}$ as have studies on the workplace clubs that were supposed to integrate the recreational activities of industrial workers with a "work culture" tailored to increased production. $^{2 \circ}$

Investigations of the repressive structures of the communist system focusing on all social groups are also informative for the issue at hand.

I s. Jindřich Pecka, “Odbory a heslo generální stávky v rezolucích z přelomu let 1968/ig69" [Trade Unions and the Slogan of the General Strike in the Resolutions from the Turn of the Year 1968-69], in Jindřich Pecka and Vilém Prečan (eds), Proměny Pražského jara 1968-1969 [Transformations of Prague Spring 1968-1969] (Prague, 1993), pp. 207-244; Jiří Mašata, "Der Kreisgewerkschaftsrat in Ostrau und die Entwicklung der Lohnsysteme 1949-1959," Bohemia, 42 (200I), pp. 307-322; Lenka Kalinová, "Die Position der tschechischen Arbeiterschaft und der Gewerkschaften zur ökonomischen und sozialen Reform in den sechziger Jahren”, Bobemia, 42 (200I), pp. 363-380.

I6. This is also true of ethnological interpretive concepts used in initial approaches analyzing working-class milieu in the communist era. See Petr Lozoviuk, "Das Alte und das Neue in einer sozialistischen 'Musterstadt'. Die Bezirksstadt Žd'ár nad Sázavou”, in Christiane Brenner and Peter Heumos (eds), Sozialgeschichtliche Kommunismusforschung. Tschechoslowakei, Polen, Ungarn und DDR 1948-1968. Vorträge der Tagung des Collegium Carolinum in Bad Wiessee vom 22. bis 24. November 2002, (Munich, 2005), pp. $48 \mathrm{I}-503$.

17. See for example Pavel Machonin, Milan Tuček, et al. (eds), Česká společnost v transformaci. K proměnám sociálni struktury [Czech Society in Transformation. On the Change in Social Structure] (Prague, 1996); Milan Tuček, Zpráva o vývoji sociálni struktury čské a slovenské společnosti 1945-1993 [Report on the Development of the Social Structure of the Czech and Slovak Society 1945-1993] (Prague, 1996); Jiř́i Večerník and Petr Matějů (eds), Ten Years of Rebuilding Capitalism: Czech Society after 1989 (Prague, I999).

I8. Dušan Janák, "Zur sozialen Lage der Bergarbeiter im Ostrau-Karwiner Revier 1945-I955”, Bohemia, 42 (2001), pp. 290-306.

I9. Jiří Knapík, "Arbeiter versus Künstler. Gewerkschaft und neue Elemente in der tschechoslowakischen Kulturpolitik im Jahr 1948", in Brenner and Heumos, Sozialgeschichtliche Kommunismusforschung, pp. 243-262.

20. Jiř́ Pokorný, "Die Betriebsklubs in der Tschechoslowakei 1945-1968. Zur Organisation sozialistischer Erziehung, Kultur und Erholung der Arbeiterschaft", in Brenner and Heumos, Sozialgeschichtliche Kommunismusforschung, pp. 263-275. 


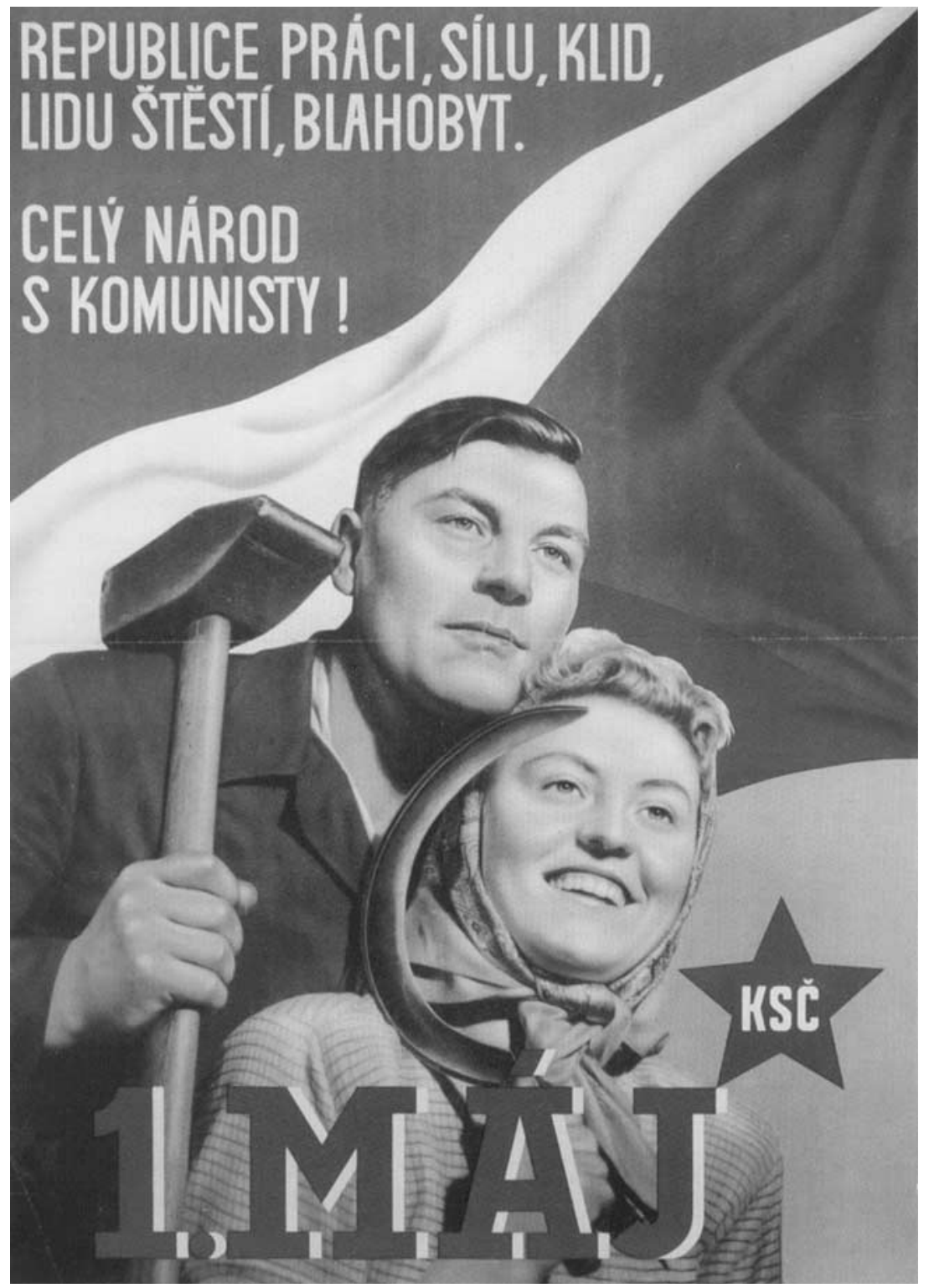

Figure 2. May Day poster of the Communist Party of Czechoslovakia (KSČ) in 1946. The Czech text reads: "Work, Strength, Peace for the Republic, Happiness, Well-Being for the People. The Whole Nation with the Communists!”.

Design: Zdenekk Rossmann, 1946. Private collection of the author. 
These include studies on labour law in the early I950s, ${ }^{21}$ penal practices of the regional courts, ${ }^{22}$ and compulsory labour camps. ${ }^{23}$ Studies of university history shed light on the inclusion of the working class in higher education; ${ }^{24}$ and editions of primary-source texts on the history of the Czechoslovakian Communist Party (KSČ) can also be fruitful for working-class history. ${ }^{25}$ The development of KSC membership has been thoroughly investigated and provides an exact picture of the changing and, after 1948, dramatically shrinking importance of workers within the party. ${ }^{26}$

When workers are the explicit focus of an investigation, entirely different conceptions of working class history are employed, as is illustrated by studies on recalcitrant behaviour, protest, and worker deviance. On the one hand, these studies follow the aforementioned pattern of elucidating the social dimensions of various "great events and major figures", and thus fit into into the predominant trends in political history. This is true, for instance, for the investigation and documentation of the industrial unrest in Brno $195 \mathrm{I}^{27}$ the depiction of the workers' strike in early June

2 I. Dalibor Státník, Sankčni pracouni právo v padesátých letech: Vládni nařżenio o opatrenich proti fluktuaci a absenci č. 52/1953 Sb. [Labor Law and Sanctions in the 1950s. Government Decree No. 52/1953 Slg. on Measures against Flucution and Absence.] (Prague, 1994).

22. Miroslav Veselka, "Komunistická justice a její oběti ve spisech okresního trestního soudu v Praze 1949-195I" [The Communist Judiciary and Its Victims in the Files of the District Criminal Court in Prague 1949-195 I], Pražský sbornık historický, 27 (1994), pp. I45-179.

23. Karel Kaplan, Tábory nucené práce v Ceskoslovensku v letech 1948-1954 [Compulsory Labor Camps in Czechoslovakia 1948-1954] (Prague, 1992).

24. John Connelly, "Students, Workers, and Social Change: The Limits of Czech Stalinism", Slavic Review, 56 (1997), pp. 307-335; idem, Captive University: The Sovietization of East German, Czech and Polish higher education, 1945-1956 (Chapel Hill, NC [etc.], 2000).

25. This is true, for example, of the two source volumes: Jitka Vondrová, Jaromír Navrátil, and Jan Moravec (eds), Komunistická strana Československa. Pokus o reformu (ř́jen I967-kvèten 1968) [The Communist Party of Czechoslovakia. The Attempted Reform (October 1967-May I968)], (Prague [etc.], 1999); Jitka Vondrová and Jaromír Navrátil (eds), Komunistická strana Ceskoslovenska. Konsolidace (květen-srpen 1968) [The Communist Party of Czechoslovakia. Consolidation (May-August 1968)] (Prague [etc.], 2000).

26. Jiří Maňák, Komunisté na pochodu kmoci. Vývoj početnosti a struktury KSČ v období 1945-1948. Studie [Communists on the Road to Power. Development of the Membership and Structure of the KSČ from 1945-1948. Study] (Prague, I995); idem, Proměny strany moci. Studie a dokumenty $k$ vývoji Komunistické strany Československa v obdobi 1948-1968 [Transformations of the Party of Power. Study and Documents on the Development of the Communist Party of Czechoslovakia from I948-1968], 2 parts (Prague, 1995); idem, Proměny

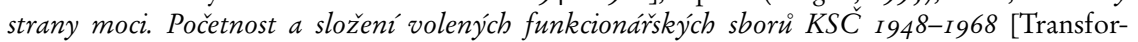
mations of the Party of Power. Number and Composition of the Elected Functionary Boards of the KSČ I948-1968] (Prague, I998); idem, Proměny strany moci. Početnost a složenípracouniku

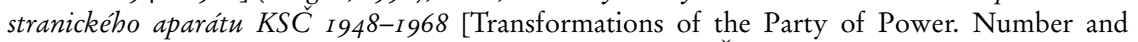
Composition of the Staff of the Party Apparatus of the KSČ 1948-1968] (Prague, I999).

27. Jiř́ Pernes, "Dělnické demonstrace v Brně v roce $195 \mathrm{I}$ " [The Worker Demonstrations in Brno in 195I], Soudobé dějiny, I (1996), pp. 23-4I; idem, Brno I95I. Př̌spěvek k dějinám protikomunistického odporu na Moravě [Brno 195I. A Contribution to the History of the 
I953 immediately after the currency reform, ${ }^{28}$ and a study on worker behaviour in $1968 .{ }^{29}$ On the other hand, these kinds of events are also taken as an opportunity to analyse from a long-term perspective protest behaviour with regard to the establishment of and the resistance to power claims by the party and state leadership within factories and firms.

This includes approaches to strike research, ${ }^{3 \circ}$ and studies on the erosion and decline of industrial socialist work initiatives on the basis of counterstrategies by workers in the first two decades after $1948 .^{31}$ These investigations broach the question of the real range of power that the communist dictatorship possessed, an issue that is explicitly addressed in analyses of the informal power position of workers in firms as the basis of protest and reproducible opposition. ${ }^{32}$

Massive objections have recently been raised to the rigid conception predominant in contemporary Czech and Slovak research - of the communist system as an "iron cage of obedience". ${ }^{33}$ This criticism is aimed at a monistic notion of power that refuses to acknowledge the results of social-historical research, which demonstrate the necessity of conceiving power relationally. According to this critique, the dividing line between "regime" and "society" introduced in the Czech totalitarian paradigm is pure mystification because the integration of the population under the

Anti-Communist Resistance in Moravia] (Prague, I997); idem, "Die Verfolgung der Teilnehmer an den Arbeiterdemonstrationen in Brünn im Jahre 195 I", in Brenner and Heumos, Sozialgeschichtliche Kommunismusforschung, pp. 355-364.

28. Zdeněk Štěpánek, Utajené povstání 1953 [The Uprising Kept Secret 1953] (Prague, 1993); Adam Skála, "Měnová reforma I. června I953 v Plzni v hlášení mocenských orgánư" [The Currency Reform on I June 1953, in Pilsen in the Reports by the Organs of Power], Minulosti západočskébo kraje, 42 (2007), pp. 602-633.

29. Lenka Kalinová, "Das Verhalten der tschechischen Arbeiterschaft im Jahre 1968", in Bernd Gehrke and Gerd-Rainer Horn (eds), 1968 und die Arbeiter. Studien zum "proletarischen Mai" in Europa (Hamburg, 2007), pp. I60-1 84.

30. Peter Heumos, "Dělnické stávky v Československu v padesátých letech" [Worker Strikes in Czechoslovakia in the I950s], Pobledy. Revue pro politiku, ekonomii, sociologii a historii, 2000:6, pp. 20-21; idem, "Zum industriellen Konflikt in der Tschechoslowakei I945-1968", in Hübner, Kleßmann, and Tenfelde, Arbeiter im Staatssozialismus, pp. 473-497.

31. Idem, "'Wenn sie sieben Turbinen schaffen, kommt die Musik'. Sozialistische Arbeitsinitiativen und egalitaristische Defensive in tschechoslowakischen Industriebetrieben und Bergwerken 1945-1965", in Brenner and Heumos, Sozialgeschichtliche Kommunismusforschung, pp. I33-I77; idem, "State Socialism, Egalitarianism, Collectivism: On the Social Context of Socialist Work Movements in Czechoslovak Industrial and Mining Enterprises, 1945-1965", International Labor and Working-Class History, 68 (2005), pp. 47-74.

32. Idem, "'Der Himmel ist hoch, und Prag ist weit!'. Sekundäre Machtverhältnisse und organisatorische Entdifferenzierung in tschechoslowakischen Industriebetrieben (1945-1968)", in Annette Schuhmann (ed.), Vernetzte Improvisationen. Gesellschaftliche Subsysteme in Ostmitteleuropa und in der DDR (Cologne [etc.], 2008), pp. 2 I-4I.

33. This according to Michal Pullmann, "Sociální dějiny a totalitněhistorické vyprávění" [Social History and the Totalitarian-Historical Narrative], Soudobé dějiny, is (2008), pp. 703-717. 
communist dictatorship was carried out on the basis of pre-political dispositions. One consequence of this empirically dubious dichotomy between "regime" and "society" is the "exoticization" of the communist system.

The accusation of "exoticizing" the era of real socialism can be well demonstrated using precisely the example of working-class history: although research on past epochs has produced studies on working-class history that satisfy the demands of modern social history, ${ }^{34}$ a kind of "special methodology" has essentially been claimed for the communist period. This claim stands and falls with the thesis - which has yet to be verified in broad realms - of the communist party's ubiquitous power over the entire society. ${ }^{35}$ This thesis is treated even more dogmatically in Slovak historiography than in Czech historiography ${ }^{36}$ - with the results anticipated by the critique $^{37}$ that Slovak historians exhibit almost no interest in the communist era. ${ }^{38}$

In the meantime, the erosion of the hardcore version of the totalitarian paradigm has also become evident. ${ }^{39}$ This can be seen, for instance, in reviews of relevant publications, which react with surprise that, in this genre, the question of grounding the communist system in the social lifeworld of the population has not been raised at all and that a view "from below" is completely lacking. ${ }^{\circ}$ The "front change" by former protagonists of this genre ${ }^{4 \mathrm{I}}$ also suggests an imminent change of course in research on historical communism. This may also be true of the tendency

34. Just one of many examples is Karel Řeháček, "Dopady války na každodenní život obyvatelstva Plzně a okolních obcí (1914-1918)" [The Effects of the War on the Everyday Lives of the Inhabitants of Pilsen and the Surrounding Townships (1914-1918)], Minulostí západočskébo kraje, 42 (2007), pp. 277-333.

35. Even the political terror that the Czechoslovakian Communist Party exercised especially in the "founding years" of the people's democracy (1948-1953) cannot, on closer inspection, be conflated with real power of disposition over the entire society, as is illustrated, by the resistance of industrial workers, which, despite the severity of Stalinist institutions, was particularly developed and, persistent in these years. See Peter Heumos, "Stalinismus in der Tschechoslowakei. Forschungslage und sozialgeschichtliche Anmerkungen am Beispiel der Industriearbeiterschaft", Journal of Modern European History, 2 (2004), pp. 82-109.

36. The prime example in Slovakia in this regard is the investigation by Jan Pešek and Robert Letz, Struktúry moci na Slovensku 1948-1989 [The Structure of Power in Slovakia 1948-1989] (Prešov, 2004).

37. Pullmann, "Sociální dějiny", p. 716.

38. Between 1990 and 2008 , three studies on the period from 1948 to 1989 were published in the leading Slovak historical journal, Historický časopis.

39. Pullmann, "Sociální dějiny", p. 716.

40. See Václav Průcha’s review of Karel Kaplan’s investigation, Proměny české společnosti 1948-1960. Ćást proni ' TTransformations of Czech Society 1948-1960. Part I] (Prague, 2007) in Soudobé déjiny, is (2008), pp. 742-75 I.

4I. Lenka Kalinová, Společenské proměny v čase socialistickébo experimentu. $K$ sociálním dejinám v letech 1945-1969 [Social Transformation in the Era of the Socialist Experiment. On the Social History between 1945 and 1969] (Prague, 2007). 


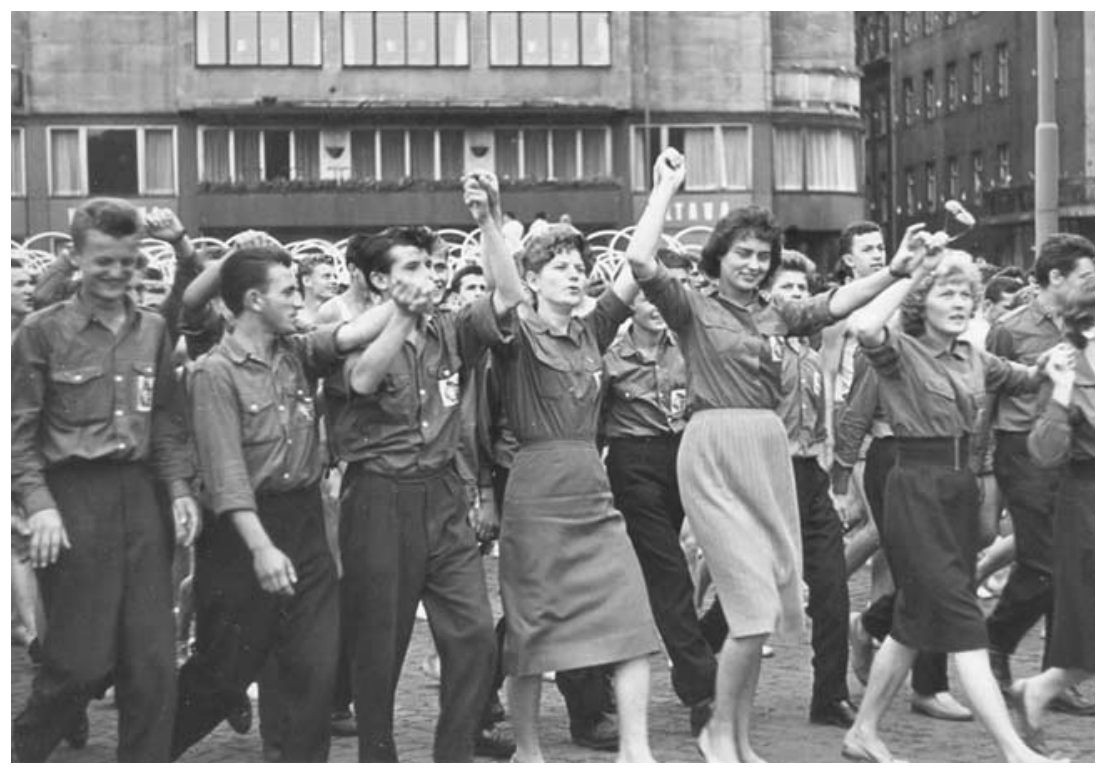

Figure 3. May Day demonstration in Prague in 1965 . In the front row are members of the Czechoslovak Youth Union.

Photograph: Private collection of the author.

in the past to tie laurel wreaths to intellectual opposition to communist rule and simultaneously furrow one's brow at certain forms of worker resistance (absence, go-slow protests, worker morale, etc.). ${ }^{42}$

The crucial issue here, however, is that this dogmatic conception of totalitarianism stands on empirically shaky ground. This is true, for instance, for examinations of the year 1968, whose brilliance lives from a kind of argumentum e contrario: the darker the "totalitarian night" of the I950s, the brighter the Prague Spring shines. The emergence of the autonomous interests of workers in I 968 - at odds with the reform course - with their critique of the party's "managerial socialism", 43 as well as everyday life in the province during the Prague Spring, ${ }^{44}$ demonstrate that

42. Anna Beinhauerová and Karel Sommer, "K některým problémům fluktuace, absentismu a pracovní morálky v průmyslových oblastech českých zemí v letech 1949-1960” [On Several Problem of the Fluctuation, Absentism, and Work Morale in the Industrial Areas of the Bohemian Lands between 1949-1960], Slezský sbormik, 89 (1991), pp. I27-I 39.

43. Peter Heumos, "Arbeitermacht im Staatssozialismus. Das Beispiel der Tschechoslowakei 1968", in Angelika Ebbinghaus (ed.), Die letzte Chance? 1968 in Osteuropa. Analysen und Berichte über ein Schlüsseljahr (Hamburg, 2008), pp. 5 I-60, 2 I 5-220.

44. Emanuel Pecka, Jindřich Pecka, and Vladimír Ungr, "Každodennost konce šedesátých let 20. století na Českobudějovicku" [Everyday Life in the Late I960s in the Region České Budějovice], Jihočeský sbornık historický, 63 (1994), pp. I85-199. 
claims about the departure of the entire Czechoslovakian society to "new shores", repeatedly emphasized and contrasted to the I950s, cannot hold up to more rigorous examination.

\section{POLISH REPUBLIC}

Traditional social-historical preferences, an open intellectual climate for the real problems of real workers, and the fact that demonstrations by workers repeatedly shook the communist system in Poland to its foundations before Solidarność induced its collapse make Polish historians' interest in workingclass history after 1989 understandable at first glance. ${ }^{45}$

In fact the history of political opposition to real socialism in Poland has also been written as working-class history marked by strikes, ${ }^{46}$ mass protests, ${ }^{47}$ street battles, ${ }^{48}$ and widespread insurgency movements. ${ }^{49}$ The parts of the workforce from which the strikers came have been elucidated for the entire duration of the People's Republic of Poland. The social structures of the working masses that flowed into Solidarnośc in the early I980s have also been well researched. ${ }^{50}$ Polish historians do admit that a

45. On Polish research on workers and the labour movement prior to 1989, see Zenobiusz Kozik, "Research into the History of the Working Class Movement in Poland in the years 1945-1987", in Marian Leczyk (ed.), La science historique polonaise dans l'historiographie mondiale (Wrocław, 1990), pp. $42 \mathrm{I}-447$.

46. On the strikes in Poland between 1945 and 1989, see Andrzej Paczkowski, Strajki, bunty, manifestacje jako "polska droga" przez socjalism [Strikes, Protests, Manifestations as the "Polish Path" through Socialism]. (Poznań, 2003); on the strikes between I945 and 1948, see Łukasz Kamiński, Polacy wobec nowej rzeczywistosí 1944-1948. Formy pozainstytucjonalnego, zywiotowego oporu spotecznego 1944-1948 [Poles in the Face of the New Reality 1944-1948. Forms of Extra-Institutional Spontaneous Social Resistance] (Torun, 2000); on the strikes between 1949 and 1952, see Jędrzej Chumiński, Ruch zawodowy w Polsce w warunkach ksztattującego się systemu totalitarnego 1944-1956 [The Trade-Union Movement in Poland under the Conditions of the Emerging Totalitarian System 1944-1956] (Wrocław, 1999); for a primary-source edition on the strikes in 1970-1971 and 1980, see Beata Chmiel and Elżbieta Kaczyńska (eds), Postulaty 1970-7I i 1980. Materiaty źródtowe wystapień pracowniczych w latach $1970-7$ I i 1980 (Gdańsk i Szczecin) [The Demands of $1970-71$ and 1980 . Source Material on the History of the Worker Demonstrations in 1970-71 and 1980 (Gdańsk and Szczecin)] (Warsaw, I998).

47. Krystyna Kersten, "Masowe protesty - proces ciągły czy odosobnione wydarzenia" [The Mass Protests - Sustained Process or Isolated Events], in Polska 1944/45-1989. Studia $i$ materiaty [Poland 1944/45-1989. Studies and Material], IV (Warsaw, 1999), pp. 28 I-302.

48. Antoni Dudek and Tomasz Marszałkowski, Walki uliczne w PRL 1956-1989 [Street Battles in the People's Republic of Poland 1956-1989] (Kraków, 1999); for an overview of the role of violence, see Włodzimierz Borodziej, "Gewalt in Volkspolen I944-1989", Osteuropa, 50 (2000), pp. I365-1 384. 49. On the year 1956, see Paweł Machcewicz: Polski rok 1956 [The Polish Year 1956] (Warsaw, 1993); on the nationwide unrest in 1970, see Jerzy Eisler, Grudzień 1970. Geneza, przebieg, konsekwencje [December 1970. Genesis, Development, Consequences] (Warsaw, 2000).

50. For a summary of the literature, see Jędrzej Chumiński and Krzysztof Ruchniewicz, "Arbeiter und Opposition in Polen 1945-1989", in Hübner, Kleßmann, and Tenfelde, Arbeiter im Staatssozialismus, pp. 425-45 I; on Solidarność, see especially Roman Laba, The Roots of 
certain "heroization" of the working class cannot always be avoided, ${ }^{5 \mathrm{I}}$ but they have attempted to work against this in various ways.

For Polish historians, it remains an open question whether the frequent worker unrest in Poland was pivotal to the changes in the political system. Did this unrest aim at a different form of the distribution of goods or at changing the principles of the political order? After 1989 - in the transition to the market economy and to democracy - this question spurred a debate, in which many participants judged the democratic potential of the working class sceptically. ${ }^{52}$ The fact that workers here have been ascribed little affinity to pluralist values ${ }^{53}$ also connects to sociological research prior to $1989 .{ }^{54}$

That the less flattering modes of worker behaviour have also been investigated suggests this is a realistic perception of the workforce. This includes, for example, the role of a significant portion of the working class in the March events of 1968, when workers allowed themselves to be drawn into the anti-Semitic smear campaign incited by the Polish United Workers' Party. ${ }^{55}$

Methodologically, Polish historians have avoided the socio-political "particularizing" of the working class through the concept of "social

Solidarity: A Political Sociology of Poland's Working-Class Democratization (Princeton, NJ, 1991).

5. Chumiński and Ruchniewicz, "Arbeiter und Opposition in Polen”, p. 448.

52. Several contributions to this debate include Józef Tischner, Etyka solidarności oraz Homo sovieticus [The Ethics of Solidarność and the Homo Sovieticus] (Kraków, I992); Janusz Reykowski, "Zmiany systemowe a mentalność polskiego społeczeństwa" [The Systematic Changes and the Mental State of Polish Society], in idem (ed.), Wartości i postawy Polaków a przemiany systemowe: szkice z psychologii [Values and Attitudes in Poland and the System Changes: Psychological Sketches] (Warsaw, 1993), pp. 9-48; Juliusz Gardawski, Przyzwolenie ograniczone. Robotnicy wobec rynku i demokracji [Limited Agreement. Workers in the Face of Markets and Democracy] (Warsaw, 1996); Anita Miszalska, Reakcje spoteczne na przemiany ustrojowe: postawy, zachowania i samopoczucie Polaków w początkach lat dziewięćdziesiątych [Social Reactions to the System Changes: The Attitudes, Modes of Behaviour, and Self-Esteem of Poles in the Early I990s] (Łódź, I996); Władysław Adamski, "Dziedzictwo strukturalne socjalizmu a zmiany ustrojowe w Polsce" [The Structural Heritage of Socialism and the Social Changes in Poland], in idem (ed.), Polacy '95. Aktorzy i klienci transformacji [Poles in '95. Actors and Clients of the Transformation] (Warsaw, 1998), pp. 19-48.

53. Jolanta Polakowska-Kujawa, "Soziale Konflikte in Polen und die Legitimierung der Macht. Wandlungen im gesellschaftlichen Bewusstsein 1945-1994", Jabrbuch der historischen Kommunismusforschung (1996), pp. 69-83.

54. Jadwiga Koralewicz, "Autorytaryzm robotników i inteligencji” [The Authoritarianism of Workers and Intellectuals], in idem, Społeczeństwo polskie przed kryzysem w swietle badań socjologicznych z lat 1977-1979 [Polish Society before the Crisis in Light of Sociological Investigations between 1977-1979] (Warsaw, 1987), pp. 80-I I0.

55. For a summary of this, see Andrea Genest, "Zwischen Anteilnahme und Ablehnung - die Rolle der Arbeiter in den Märzereignissen 1968 in Polen", in Gehrke and Horn, I968 und die Arbeiter, pp. I 8 5-209. 
resistance", ${ }^{6} 6$ a move that has also been supported institutionally by the activities of the Instytut Pamięci Narodowej (Institut for National Thought) and the KARTA Centre. ${ }^{57}$ This concept re-enacts the approach of "social self-organization", through which the democratic opposition in Poland began in the mid-i970s to address society itself rather than the state as its primary interlocutor. These ideas gave rise in 1976 to the Komitet Obrony Robotników (Committee for the Defence of Workers), ${ }^{58}$ whose significance as "a civic movement of moral resistance" 59 lay in the fact that extremely diverse social groups accepted its programme and that it enabled a rapprochement between the Catholic Church and the opposition. This concrete socio-political generalization of dissent, protest, and resistance, which the mass movement Solidarność was able to utilize at the beginning of the I980s, also made possible numerous publications that closely tied working-class history and social history - whether from the standpoint of the working class's relations to the changing power elites, ${ }^{60}$ the position of workers during critical upheavals, ${ }^{61}$ or workers' state of consciousness in relation to other social groups. $^{62}$

Evidently this is one way to get away from the figures of thought in Cold War literature, in which every form of protest in real socialism was elevated to fundamental opposition to the communist system. Especially sociological investigations have worked against this kind of interpretation by demonstrating under which socio-structural conditions actions representative of broad strata were possible under communist rule. ${ }^{63}$

56. Authoritative here is Andrzej Friszke, Polska. Losy państwa i narodu 1939-1989 [Poland. The Fate of the State and the Nation 1939-1989] (Warsaw, 2003).

57. Krzysztof Ruchniewicz, "Antistalinisten und Chartisten, Reformer und politische Aussteiger. Die verschiedenen Oppositionsgenerationen im real existierenden Sozialismus", in Bispinck, Danyel, Hertle, and Wentker, Aufstände im Ostblock, pp. 275-285.

58. Jan Józef Lipski, KOR: A History of the Workers' Defence Committee in Poland, 1976-I98I (Berkeley, CA [etc.], I985). On the long-term social presuppositions for the founding of the KOR, see Jędrzej Chumiński, "Formy obrony interesów pracowniczych w warunkach totalizacji życia społecznego (1949-1956)" [Forms of the Defending Employee Interests during the Totalitarian Reshaping of Social Life (1949-1956)], Studia Historyczne, 42 (1999), pp. 91-I Io. 59. Ruchniewicz, "Antistalinisten und Chartisten", p. 283.

60. Hanna Świda-Ziemba, "Robotnicy lat pięćdziesiątych" [Workers in the I950s], in Przemysław Wójcik (ed.), Elity wtadzy w Polsce a struktura spoteczna w latach 1956-I98I [Power Elites in Poland and the Social Structure between I956 and I98I] (Warsaw, I994), pp. I I-49. 6I. Leszek Gilejko, Robotnicy i spoteczeństwo: 1980-I98I, 1989-1990 [Workers and Society: 1980-1981, 1989-1990] (Warsaw, 1995).

62. Maciej Jarosz, "Robotnicy '56-'57: czy rozczarowanie komunizmem?" [The Workers of 1956-57: Disappointed by Communism?], in Tomasz Szarota (ed.), Komunizm. Ideologia, system, ludzie [Communism. Ideology, System, the People] (Warsaw, 200I), pp. 325-337.

63. Piotr Sztompka, Socjologia. Analiza spoteczenistwa [Sociology. The Analysis of Society] (Kraków 2002). 
Approaches to comparative protest research for eastern central Europe also affirm methodological efforts to socially "fortify" the notion of resistance. ${ }^{64}$

This concept shifts attention to group-specific distinctions and simultaneously to the question of adaptation to existing circumstances, ${ }^{65}$ an issue that investigations of workplace history have also pushed into the foreground: focusing on the control of firms by the party and by labour unions and on the activities of security forces helps to illuminate adaptations made in everyday life.

Investigations of workplace history with a primary interest in the everyday life of workers ${ }^{66}$ - including examinations of the subcultural milieu, especially of young workers in model socialist cities such as Nowa Huta $^{67}$ - attained a level early on ${ }^{68}$ that suggested comparisons with other socialist countries. ${ }^{69}$

64. On this, see Łukasz Kamiński (ed.), Z badań nad oporem spotecznym w Europie Srodkowej w latach 1948-1955 [From Research on Social Resistance in Central Europe between 1948 and 1955] (Warsaw, 2000); Krzysztof Ruchniewicz (ed.), Powstanie czerwcowe w NDR w 1953 roku na tle innych wystapień antykomunistycznych w krajach Europy Srodkowo-Wschodniej [The June Uprising in the GDR in 1953 before the Background of other Anti-Communist Uprisings in the Countries of Central Europe] (Wrocław, 2003).

65. Hanna Świda-Ziemba, Cztowiek wewnętrznie zniewolony. Mechanizmy i konsekwencje minionej formacji - analiza psychologiczna [The Internally Unfree Person. Mechanisms and Consequences of the Past Formation - A Psychological Analysis] (Warsaw, 1997); Mirosława Marody, "Przemiany postaw ideologicznych i przysostowanie w systemie komunistycznym" [Changes in the Ideological Attitudes and Adaptation in the Communist System], in Szarota, Komunizm, pp. I27-I 38; Dariusz Jarosz, "Stalinizm polski 1948-1956: strategie przystosowawcze" [Polish Stalinism 1948-1956: Strategies of Adaptation], in Gregorz Miernik (ed.), Polacy wobec PRL. Strategie przystosowawcze [Poles and the People's Republic of Poland. Strategies of Adaptation] (Kielce, 2003), pp. 5 I-65.

66. Błażej Brzostek, Robotnicy Warszawescy. Konflikty codzienne 1950-1954 [Warsaw Workers. Everyday Conflicts 1950-1954] (Warsaw, 2002).

67. Bolesław Janus, "Labor's Paradise: Family, Work and Home in Nowa Huta, Poland, 1950-1960", East European Quarterly, 33 (2000), pp. 453-474; Dagmara Jajeśniak-Quast, "Soziale und politische Konflikte der Stahlarbeiter von Nowa Huta während der sozialistischen Transformation”, Bohemia, 42 (200I), pp. 244-268.

68. Marek Ziółkowski (ed.), Robotnicy '84-'85. Swiadomość pracowników czterech wielkich zaktadów przemystowych [Workers 1984-85. The Consciousness of the Employees of Four Large Industrial Firms] (Wrocław, I990); Dorota Jagodzińska-Sasson et al., in Marcin Kula (ed.) PZPR w fabryce. Studium wroctawskiego "Pafawagu" w początku lat pięćdziesiatych [The Polish United Workers' Party in the Factory. A Study of the Wrocław Pafawag Works in the Early 1950s] (Warsaw, 200I); Henryk Słabek, "Załoga fabryczna (jedność i sprzeczność) 1945-1989" [The Factory Workforce (Unity and Contrariness) 1945-1989], Dzieje najnowsze, 35 (2003), pp. I I $3-\mathrm{I} 42$.

69. Małgorzata Mazurek, Socjalistyczny zakład pracy. Porównanie fabrycznej codzieności w PRL i NRD u progu lat sześćdziesiatych [The Socialist Firm. A Comparison of Everyday Factory Life in the People's Republic of Poland and the German Democratic Republic in the Early i970s] (Warsaw, 2005). 
Drawing upon research on working-class milieu and traditions in Poland,$^{70}$ investigations have also depicted the forms of surveillance of these milieus. ${ }^{71}$ Studies on the control of firms and factories through workplace committees of the party and trade unions also exist. ${ }^{72}$ Numerous investigations have examined the oppositional strategies of workers that aimed at avoiding surveillance and disciplinary action. ${ }^{73}$ Work by women in industrial plants has also been analysed within the scope of research on women's occupational labour. ${ }^{74}$ Whereas prior to 1989 worker discipline and productivity were usually treated critically, ${ }^{75}$ the work ethos now receives its due, ${ }^{76}$ without neglecting the phenomenon of "amoral familiarism," that is, those corrupt and illegal practices in everyday life (not only that of workers), which reflect the fact that moral and legal criteria lose their validity outside of "local" environs. ${ }^{77}$ Finally, studies on the lifestyles of workers are also part of the broad spectrum of issues concerning working-class history. ${ }^{78}$

70. Padraic Kenney, Rebuilding Poland: Workers and Communists, 1945-1950 (London, I996). 71. Jędrzej Chumiński, "Formy nadzoru środowiska pracowników przemysłu w latach forsownej industrializacji (1949-1956)" [Forms of Surveillance of the Milieu of Industrial Workers in the Years of Forced Industrialization (1949-1956)], Studia Historyczne, 4I (1998), pp. $557-575$.

72. Dariusz Jarosz, "Notatka o sytuacji w Nowej Hucie z października I955 roku” [Record of the Situation in Nowa Huta from October 1955], in Polska 1944/45-1989. Studia i materiaty, II (Warsaw, 1997), pp. 309-330; Maciej Tymiński, PZPR i przedsiębiorstwo. Nadzór partyjny nad zaktadami przemystowymi 1956-1970 [The Polish United Worker's Party and the Firm. The Surveillance of Industrial Plants by the Party 1956-1970] (Warsaw, 2001).

73. Winicjusz Narojek, Socjalistyczne "Welfare State". Studium z psychologii spotecznej Polski Ludowej [The Socialist "Welfare State". Study on the Social Psychology of People's Poland] (Warsaw, I991); Krzysztof Konecki, Novi pracownicy a kultura organizacyjna. Studium folkloru fabrycznego [The New Employees and Organizational Culture. A Study of Factory Folklore] (Łódź, I992); Łukasz Kamiński (ed.), Studia i materiaty z dziejów opozycji i oporu spotecznego [Studies and Materials on the History of the Opposition and the Social Resistance]. 4 vols (Wrocław, I998-2000).

74. Dariusz Jarosz, "Kobiety i praca zawodowa w Polsce w latach 1944-1956 (główne problemy w świetle nowych badań źródłowych)" [Women and Occupational Labour in Poland between 1944 and 1956 (Main Problems in Light of New Studies of Sources)], in Anna Żarnowska and Andrzej Szwarc (eds), Kobieta i praca. Wiek XIX $i$ XX. Zbiór studiów [Women and Work: The Nineteenth and Twentieth Centuries. Anthology], VI (Warsaw, 2000), pp. 2 I7-24I. 75. See Mazurek, "Das Alltagsleben”, p. 303.

76. Julian Burgiel et al., Praca jako wartość w świadomości zatogi przedsiębiorstwa przemystowego: raport z badan' [Work as a Value in the Consciouness of the Workforce of an Industrial Enterprise: A Research Report] (Kraków, 1990).

77. Elżbieta Tarkowska, Jacek Tarkowski, “Amoralny familizm', czyli o dezintegracji społecznej w Polsce lat osiemdziesiątych" ["Amoral Familiarismus” or on the Social Disintegration in Poland in the 1980 s], in Jacek Tarkowski (ed.), Wtadza i spoteczeństwo w systemie autorytarnym [Power and Society in the Authoritarian System], I (Warsaw, I994), pp. 263-282. 78. Henryk Słabek, "Stył życia robotników polskich 1945-1989" [The Lifestyle of Polish Workers 1945-1989], Dzieje najnowsze, 34 (2002), pp. 47-72. 
Although conceptual precautions have, as we have seen, been taken to prevent working-class history from drifting off to a special status, there continue to be critical voices as well: advocates of the ethos of martyrdom and resistance inherited from of the resistance of World War II still favour both oppositional actions and spectacular revolts and conceal conformist attitudes by workers. ${ }^{79}$ They do not regard references to the unresponsiveness of workers to communist ideology, ${ }^{80}$ and to the extensive failure of totalitarianism in Poland ${ }^{8 \mathrm{I}}$ as helpful. Instead they argue, supported by grassroots sources, ${ }^{82}$ that workers thoroughly internalized the communist promesse $d n$ bonbeur of a "better life", but that they continued to experience "relative discrimination" under communist rule. The growing discrepancy between expectations and reality, they insist, has been crucial in workers repeatedly taking their affairs into their own hands. ${ }^{83}$

\section{HUNGARIAN REPUBLIC}

A central focus of working-class history in Hungary after 1989 has undoubtedly been the Stalinist period from I $948-1956$. One indication of a systematic interest in this phase is that primary-source editions on working-class history under communist rule began with this period. ${ }^{84}$ For the Institute for the History of the 1956 Hungarian Revolution in Budapest, the years $1948-1956$, as the prehistory of the popular uprising in the fall of 1956 , stand at the centre of its research interests, although these are oriented around political history. The most important publications of the institute include the documentation of the Revolution of $1956 .{ }^{85}$

79. On this, see the introductory comments in Mazurek, "Das Alltagsleben", p. 29I.

80. Andrzej Walicki, Zniewolony umyst po latach [The Unfree Spirit After Years] (Warsaw, I993); Janusz Żarnowski, “Robotnicy w Polsce Ludowej” [Workers in People’s Poland], Dzieje najnowsze, 34/I (2002), pp. 29-46.

8 I. Krystyna Kersten, “Czy PLR była państwem totalitarnym?” [Was the People’s Republic of Poland a Totalitarian State?], Mówia wieki, 35:2 (1992), pp. I-7.

82. Fruitful for working-class history are, among other things, self-written resumees by workers. See Aurelia Szafran-Bartoszek, Andrzej Kwilecki et al. (eds), Robotnicze losy. Zyciorysy wtasne robotników [Worker Fates. Autobiographies of Workers] (Poznań, 1996). Informative are the complaints ("input") to the government, for the most part from workers. See Anna Dzierżgowska et al. in Marcin Kula (ed.), Supliki do najwyzszej wtadzy [Input to the Government (Warsaw, 1996). An important source for social history is complaint letters by workers; Bartholomew Goldyn, "Letters of Complaints as a Source for the Social History of Poland: The Case of Nowa Huta", The Polish Review, 45 (2000), pp. 356-366.

83. In a broad social-historical context, see Marcin Zaremba, "Am Rande der Rebellion. Polnische Arbeiter am Vorabend des Arbeiteraufstandes im Dezember 1970", in Gehrke and Horn, 1968 und die Arbeiter, pp. 2 10-228.

84. Gyula Belényi and Lajos Varga (eds), Munkások Magyarországon 1948-1956. Dokumentumok [Workers in Hungary 1948-1956. Documents] (Budapest, 2000).

85. Csaba Bekes, Malcolm Byrne, and Janos Rainer (eds), The 1956 Hungarian Revolution: A History in Documents (New York, 2002); the original edition in Hungarian appeared in 1996 in 
Outside the institute, the history of the workers' councils in the uprising of 1956 was quickly updated after $1989 .{ }^{86}$

Research on Stalinism, however, has not been conceived in such a way that the uprising of 1956 serves as its vanishing point. Studies on social change in Hungary during the second half of the twentieth century disqualify the assumption that a surfeit of social problems existed in the revolutionary year of $1956{ }^{87}$ Investigations of Hungary's cultural development in the second half of the twentieth century that include the cultural situation of workers do not point to any profound ruptures in 1956. ${ }^{88}$ In addition, studies assessing the human and social costs that Stalinist industrialization demanded of Hungarian workers have resisted the temptation of depicting worker's reactions to terror, violence, and impoverishment as a cumulative process that reached its climax in $1956 .{ }^{89}$ These studies are driven to large degree by reflections on how workingclass history can be combined with anthropological research, ${ }^{90}$ and they are more interested in the diversity of the social causes of worker protest than in the conditions under which such protest was manifested politically. ${ }^{91}$ Research on the working-class milieu - the milieu of the "new working class" that the party attempted to recruit from its own supporters is also considered here ${ }^{22}$ - suggest that the social "penetration depth" of

Budapest: Az 1956-oz magyar forradalom lengyel dokumentumai. See also György Varga, "Zur Vorgeschichte der ungarischen Revolution von 1956", in Jan Foitzik (ed.), Entstalinisierungskrise in Ostmitteleuropa 1953-1956. Vom I7. Juni bis zum ungarischen Volksaufstand. Politische, militärische, soziale und nationale Dimensionen (Paderborn, 200I), pp. 55-77. For the most recent literature on the Hungarian revolution, see Árpád von Klimó and Alexander Kunst, "Krisenmanagement und Krisenerfahrung. Die ungarische Parteiführung und die Systemkrisen 1953, 1956 und 1968", in Bispinck, Danyel, Hertle, and Wentker, Aufstände im Ostblock, pp. 287-307.

86. Bill Lomax (ed.), Hungarian Workers' Councils in 1956 (Boulder, CO, 1990).

87. Tibor Valuch, Magyarország társadalomtörténete a XX. század második felében [The Social History of Hungary in the Second Half of the Twentieth Century] (Budapest, 200I).

88. Idem, "A Cultural and Social History of Hungary 1948-1990", in László Kósa (ed.), A Cultural History of Hungary in the Nineteenth and Twentieth Centuries (Budapest, 2000), pp. 249-348.

89. Gyula Belényi, A sztálini iparositás emberi ára 1948-1956 [The Human Price of Stalinist Industrialization 1948-1956] (Szeged, I993).

90. Sándor Horváth, László Pethő, and Zsófia Eszter Tóth (eds), Munkástörténet-Munkásantropológia. Tanulmányok [Working-Class History - Working-Class Anthropology. Essays] (Budapest, 2003).

91. Mark Pittaway, "Retreat from Collective Protest: Household, Gender, Work and Popular Opposition in Stalinist Hungary," in Jan Kok (ed.), Rebellious Families: Household Strategies and Collective Action in the Nineteenth and Twentieth Centuries (Oxford [etc.], 2002), pp. 198-228.

92. Sándor Horváth, "Der ungarische Stachanow Imre Muszka", in Rainer Gries and Silke Satjukow (eds), Sozialistische Helden. Eine Kulturgeschichte von Propagandafiguren in Osteuropa und der DDR (Berlin, 2002), pp. 214-2 I9. 
the peripetia of political developments was minor. Connecting to older studies of local history, ${ }^{93}$ scholars have outlined the working-class milieu for a particular city district or city. Examples of this are investigations of the Budapest working-class district of Ujpest ${ }^{94}$ and of everyday life in the model socialist city of Sztálinváros. ${ }^{95}$

Studies on the history of trade unions have also concentrated on the terrorist phase of the party dictatorship (1948-1956), ${ }^{96}$ and have shown that the founding of communist trade unions was carried out over the heads of a disempowered workforce, which under the Horthy dictatorship and Nazi occupation had lost its connection to trade unions committed solely to the ideology and practices of social peace. ${ }^{97}$ Historians regard this stripping of workers' organizational ties in society along with the ensuing social and moral consequences as an essential preliminary stage, if not the most important precondition, for the far-reaching adaptation of workers to the authoritarian-repressive structures of the early phase of the socialist transformation..$^{98}$

This is the point of departure for a series of investigations with two explicit objectives. First, they demonstrate that socialist industrialization (which might have been especially rigid in Hungary) evoked a countermovement by workers in factories, through which they were able to mitigate the dictate of ever increasing planning goals by means of informal agreements with workplace and local power elites, and thereby harmonized these goals with their own traditional "production culture". Second, this informal power position of workers has served as the starting point for the social history of a "production regime" generated "from below", which is distinguished from standard portrayals of the history of economics and planning under state socialism as the history of its institutional framework.

93. Gábor Gombkötö and Albert Antalóczy (eds), Tatabánya Története. Helytörténete Tanulmányok I-II. [History of Tatabánya. Studies on Local History.], I-II (Tatabánya, I972).

94. András Berényi and Sándor Kasza, Újpest IV Kerület [Újpest. The Fourth District] (Budapest, 1998).

95. Sándor Horváth, “Alltag in Sztálinváros. Die 'Zivilisierten' und die 'Wilden' in der ersten sozialistischen Stadt Ungarns", in Brenner and Heumos, Sozialgeschichtliche Kommunismusforschung, pp. 505-526; Ferenc Erdős and Zsuzanna Pongrácz (eds), Dunaújváros története [History of Dunaújváros] (Dunaújváros, 2000).

96. Lajos Varga, Szakszervezetek a Diktatúrában. A Magyar Dolgozók Pártja és a szakszervezetek, I948-1953 [Trade Unions in the Dictatorship: The Hungarian Workers' Party and the Trade Unions, 1948-1953] (Pécs, 1995).

97. Péter Sipos, Die Sozialdemokratische Partei Ungarns und die Gewerkschaften I890-1944 (Budapest, I991).

98. László Varga, Az elhagyott tömeg. Tanulmányok 1950-1956-ról [The Absent Masses. Studies on the Year 1950-1956] (Budapest, 1994); János Jemnitz, The Forward March of the Left and the Problems of its Progress 1945-1948 (Budapest, 200I). 
In addition to a brief outline of this research programme, which emphasizes the limits of state control over the production process, ${ }^{99}$ this approach has also been applied to two different complexes during the early phase of the socialist transformation: the attempts by workers to informally regulate work-time and wages; ${ }^{100}$ and the bargaining strategies of the skilled workers who sought to maintain or reintroduce within the workforce hierarchies tied to traditional working-class culture, in which a generational conflict between older and younger skilled labourers was also evident. ${ }^{\text {IOI }}$ This approach has proved equally productive when applied to the economic reforms under Kádár in $1968,{ }^{102}$ which did contribute to some degree to the political pacification of the workforce, but were also eroded over the long-term through the informal "production regime". ${ }^{103}$ The report by a "key worker" at the Red Star tractor factory in Budapest suggests that the concept outlined above of the informal adaptation of the planning system to social relations at the workplace does in fact do justice to Hungarian reality. ${ }^{104}$

Like their Polish counterparts, Hungarian researchers have also examined the contemporary question of how four decades of communist rule effected the workforce, in other words: how the resource "labour" available for the Hungarian path to capitalism was procured. This includes analyses of the labor market ${ }^{105}$ and investigations of worker behaviour in the changing social and workplace constellations. ${ }^{\text {I06 }}$

In addition to the emphasis on the Stalinist dictatorship, long-term investigations of the social situation of the workforce after 1956 also point

99. Mark Pittaway, “Az állami ellenőrzés társadalmi korlátainak újraértékelése: az ipari dolgozók és szocialista diktatúra Magyarországon, I948-1953” [A Re-evaluation of the Social Limits of State Control: The Industrial Worker in Hungary's Socialist Dictatorship, 1948-1953], in Horváth, Pethő, and Eszter Tóth, Munkástörténet-Munkásantropológia, pp. 7I-82.

Iо०. Idem, "The Social Limits of State Control: Time, The Industrial Wage Relation and Social Identity in Stalinist Hungary, 1948-1953", Journal of Historical Sociology, I2 (1999), pp. $27 \mathrm{I}-30 \mathrm{I}$.

I0I. Idem, "The Reproduction of Hierarchy: Skill, Working-Class Culture and the State in Early Socialist Hungary", The Journal of Modern History, 74 (2002), pp. 737-769; idem, "Workers, Management and the State in Socialist Hungary: Shaping and Re-Shaping the Socialist Factory Regime in Újpest and Tatabánya, 1950-1956", in Brenner and Heumos, Sozialgeschichtliche Kommunismusforschung, pp. 105-1 3 I.

102. Nigel Swain, Hungary: The Rise and Fall of Feasible Socialism (London [etc.], 1992).

I03. Mark Pittaway, "Accommodation and the Limits of Economic Reform: Industrial Workers during the Making and Unmaking of Kádár's Hungary”, in Hübner, Kleßmann, and Tenfelde, Arbeiter im Staatssozialismus, pp. 453-47 I.

I04. This report is used in Michael Burawoy and János Lukács, The Radiant Past: Ideology and Reality in Hungary's Road to Capitalism (Chicago, IL [etc.], I992).

ıо5. Károly Fazekas and János Köllö, Munkaeröpiac Tökepiac Nélkül [The Workforce Market without Capitalism] (Budapest, 1990).

106. Lajos Héthy and Csaba Makó, Patterns of Workers' Behaviour and the Business Environment (Budapest, 1989). 
to the emergence of a second focus in Hungarian research on communism. As in Poland, these investigations presuppose, on the one hand, a conflict between ideological representations of the working class and the real experiences of workers under communist rule; at the same time, these investigations also elucidate how the Hungarian Socialist Workers' Party dealt with this contradiction, which it found worrisome at times. ${ }^{107} \mathrm{On}$ the other hand, changes in "working-class life" in Hungary have also been analysed from a long-term perspective, a research orientation strongly influenced by the aforementioned anthropological interest and that connects the issue of "working-class life" beyond material indicators of living standards to psychic-mental structures, ties to traditional values, private and public modes of social behaviour, and cultural orientations. ${ }^{108}$ Related to this are also studies on the self-conception of female factory workers. ${ }^{109}$

\section{REPUBLIC OF ROMANIA}

"New scholarship on the Romanian working class is almost non-existent", someone who ought to know wrote in the spring of 2009. ${ }^{\text {IIO }}$ The only thing that should be added here is that the methodological-conceptual approach to Romanian working-class history in real socialism is more research-intensive in many respects than, for instance, in Poland or Hungary; nevertheless, the few existing investigations of working-class history here are promising.

As a major social group, the Romanian workforce is a product of the country's socialist industrialization. Around 1930 industrial workers comprised approximately 8 per cent of the entire population. For this reason, an interpretive model that is widely used for obvious reasons by Czech, Polish, and Hungarian scholars cannot be applied to the history of the Romanian working class: the examination of the strategies used in conflicts between working-class traditions and the demands of the new reality under the communist dictatorship. The history of Romania's social democracy rewritten after 1989 makes clear that Romanian workers had no recourse to political traditions: ${ }^{\text {II }}$ while the study does allude to connections between the party and the workforce, it cannot get around the fact that the social basis of

I07. Anikó Eszter Bartha, "The Disoyal 'Ruling Class': The Conflict between Ideology and Experience in Hungary”, in Hübner, Kleßmann, and Tenfelde, Arbeiter im Staatssozialismus, pp. I4I-I62.

I08. Józef Kovács, "Arbeiterexistenz in Ungarn nach 1956. Einige Schnittpunkte der Mikround Makrogeschichte," in Hübner, Kleßmann, and Tenfelde, Arbeiter im Staatssozialismus, pp. 319-345.

ı09. Eszter Zsófia Tóth, "Shifting Identities in the Life Histories of Working-Class Women in Socialist Hungary", International Labor and Working-Class History, 68 (2005), pp. 75-92.

I IO. Letter from Romanian historian Dragoş Petrescu to the author, I 2 April 2009.

I I I. Nicolae Jurca, Istorija social-democraţiei din România [The History of Romania’s Social History] (Bucarest, I994). 
Romanian social democracy during the interbellum period was shaped above all by low-level white-collar employees. ${ }^{\text {II2 }}$ In fact only after World War II was there a larger influx of workers into the party as a result of the collapse of the old party system. ${ }^{\text {II3 }}$

For this reason, far more than elsewhere, Romanian workers were confronted with the necessity of learning processes. The fact that between I950 and 1989 there were only thirty-six known cases of worker strikes, demonstrations, and revolts in Romania - limited almost every time to a single factory ${ }^{\mathrm{II}}$ - should thus be attributed not only to the (undisputed) brutality of the Ceaussescu regime. Even where workers could draw upon a long tradition of collective action - for example, in Czechoslovakia - it still took some time before they were able to identify which means should be used in confronting the state and the party in order to attain their demands. ${ }^{\text {IS }}$ Comparisons with other countries could in fact help avoid rashly labelling Romania a "special case".

The self-perception of Romanian workers does not seem to have deviated significantly from the characteristics observed everywhere in real socialism. ${ }^{116}$ Similarities to other countries are evident in conflict behaviour, for miners, for instance, who in both Romania and Czechoslovakia retained paternalistic patterns of interaction in the sense that in conflicts they insisted on face-to-face communication with the most senior political representatives and rejected subordinate officials as negotiating partners. ${ }^{17}$ Furthermore, even with the limited strike sample for Romania, a long-term change is evident: between the two major strikes that took place in socialist Romania - the miners' strike in the Jiu Valley in August 1977 and the Braşov revolt at the Steagul Roşu tractor factory in November $1987-$ a transition occurred from social demands to political protest against the communist system and explicitly against Ceauşescu. ${ }^{I 18}$

I I 2. Joseph Rothschild, East Central Europe between the Two World Wars (Seattle, WA [etc.], 1998), p. 295 .

I I3. Jurca, Istorija social-democrației, p. 329.

I I4. On this, see the annotated list of demonstrations and strikes in Dragoș Petrescu, "Workers and Peasant-Workers in a Working Class 'Paradise': Patterns of Working Class Protest in Communist Romania", in Hübner, Kleßmann, and Tenfelde, Arbeiter im Staatssozialismus, pp. I I9-I 40; idem, "A Threat from Below? Some Reflections on Workers' Protest in Communist Romania”, Xenopoliana, 7 (1999), pp. I42-168.

I I 5 . On this, see the contributions cited in n. 30.

I 16. Jack Friedman, "Furtive Selves: Proletarian Contradictions, Self-Presentation, and the Party in I950s Romania", International Labor and Working-Class History, 68 (2005), pp. 9-23. I 17. Cristina Petrescu and Dragoș Petrescu, "Resistance and Dissent under Communism - The Case of Romania", Totalitarismus und Demokratie, 4 (2007), pp. 323-346; for Czechoslovakia, see the contributions cited in $\mathrm{n} .30$.

I 8 . Ibid., pp. 330-336; for details on the strike in the Jiu Valley, which began in the Lupeni mine, see Mihai Barbu and Gheorghe Chirvasă, După 20 de ani: Lupeni '77-Lupeni '97 [Twenty Years Later: Lupeni 1977-Lupeni 1997] (Petroţani, 1997); eyewitness reports of the 
Romanian researchers have focused on the phenomenon of the peasantworker, which Romania shared with Bulgaria, Hungary, Poland, and Czechoslovakia, although the numerical size of this group varied in the different countries. A quick glance at the changing social behaviour of this group from country to country indicates that this part of the workforce, which oscillated between factory work and sideline agricultural labour, deserves closer investigation. ${ }^{\text {I9 }}$ For Czechoslovakia - where in the midI950s peasant-workers comprised around one-third of all working class households - scholars have argued that the kovorolnici (iron peasants) represented a kind of "rest mass" of the industrial workforce on the basis of their social distance to the industrial milieu; ${ }^{120}$ in Romania, in contrast, where peasant workers made up 30 to 50 per cent of the workforce, they evidently constituted a ferment of protest and unrest. When the protest broke out in Timişoara on I6 December I989, which led to the collapse of the Ceauşescu regime a few days later, Moldavian peasant-workers stood in the front lines of the rebelling crowd. ${ }^{\mathrm{I} 2 \mathrm{I}}$

The investigation of working-class history in Romania between 1948 and 1989 has drawn productively in several ways from transformation research. ${ }^{122}$ This history will gain clearer contours when it can be evaluated before the background of more precise knowledge about other social groups. ${ }^{\text {I23 }}$ The analysis of these groups has been overshadowed for the time being by the focus on the terror, control, and repressive apparatuses of the party dictatorship. ${ }^{\mathrm{I}} 4$ This has sparked a debate about the character of the Ceauşescu era, in which the focus has shifted more to issues of the regime's social resonance than its repressive apparatuses. ${ }^{\mathrm{I2}}$

worker revolt in Braşov are published in Romulus Rusan (ed.), O zi de toamnă, cindva ... IS noiembrie 1987, Braşov [A Day in Autumn, some time ... November I5, 1987, in Braşov] (Bucarest, 2004).

I 19. On the basis of the findings at the international colloquium "Workers in State Socialism" at the Centre for Contemporary Historical Research in Potsdam, Germany in September 2003, it was agreed to establish a study group devoted specially to peasant-workers in real socialism. I 20. Peter Heumos, "Aspekte des sozialen Milieus der Industriearbeiterschaft in der Tschechoslowakei vom Ende des Zweiten Weltkrieges bis zur Reformbewegung der sechziger Jahre", Bobemia, 42 (200I), pp. 323-362.

I 2 I. Petrescu, "Workers and Peasant-Workers", p. I33.

I 22. Thomas J. Keil and Jacqueline M. Keil, "Reconstructing a Legal Basis for Capitalist Labor Relations in Post-Revolutionary Romania”, East European Quarterly, 4I (2007), pp. 239-27I. I 23. A desideratum emphasized by Romanian historians; on this see, for instance, Petrescu and Petrescu, "Resistance and Dissent".

I 24. For the period prior to Ceaușescu, see Dennis Deletant, Terror Communist in Romania: Gheorghiu-Dej and the Police State, 1948-1965 (New York, 1999); for the entire communist era, see Corina Marculesa, "Captive Romania: Police Terror and Ideological Masquerade under Communist Rule”, East European Quarterly, 4I (2008), pp. 383-406.

I 25. This is the context of the thesis, supported by several authors, that although no serious attempt was made to "de-Stalinize" under Ceaușescu, the regime did as a whole place more 


\section{REPUBLIC OF BULGARIA}

According to a study from 2005 , the issue of "workers in state socialism" has "not yet been discovered" as a subject of contemporary historical research in post-1989 Bulgaria. ${ }^{\mathrm{I} 26}$ Scholars have, however, begun to approach the issue from several directions. Social-historical studies focusing on the time period from the I960s to the mid-I990s and incorporating the most important social development trends even outside Bulgaria have described the workforce as an essentially stabilizing element of Bulgarian state socialism. ${ }^{\mathrm{I} 27}$ In doing so, they can point to the fact that no noteworthy strikes or other form of worker protest were documented in Bulgaria after 1956 until the collapse of real socialism in the country in $1989 .{ }^{128}$

According to political-historical accounts, the Bulgarian Communist Party could especially count on workers when the wage system produced egalitarian structures and the economic system maintained orthodox notions of order. Formulated slightly differently, workers stigmatized as socially unjust and - in agreement with intra-party oppositional and leftist dissident groups - as a "betrayal of socialism" distinctions in performance and wages as well as the transition to a decentralized and liberalized economic order, as occured within the scope of economic reforms in the 1960s. ${ }^{\text {I29 }}$ Transformation research, which analyses Bulgaria's transition to capitalism, has proved fruitful for information about the development of workers' standards of living since the 1960 s. $^{130}$ The reconstruction of tradeunion history ${ }^{\mathrm{I} 3 \mathrm{I}}$ has also proceeded rapidly because in the 1980 s the research institute of the Bulgarian trade-union federation conducted a series of nationwide sociological investigations into the situation of workers, which have provided important insights into their everyday life. ${ }^{\mathrm{I} 32}$

Another group of investigations influenced by ethnology and cultural history has focused on Bulgarian society in the nineteenth and twentieth centuries. These investigations are organized primarily around the issue of

emphasis on "cooptation” than terror. See Vladimir Tismăneanu, Stalinism for All Seasons: A History of Romanian Communism (Berkeley, CA, 2003).

I26. Ivo Georgiev, "Die Arbeiter als Modernisierungsbremse im realsozialistischen Bulgarien?", in Hübner, Kleßmann, and Tenfelde, Arbeiter im Staatssozialismus, pp. I09-ı I 8.

I27. Nikolai Genov and Angela Krasteva (eds), Bulgaria 1960-1995: Trends of Social Development, National and Global Development (Sofia, 1999).

I 28. Georgiev, "Die Arbeiter," p. I I.

I29. Dimităr Ivanov, Protivopostavjaneto 1956-1989 [The Confrontation 1956-1989] (Sofia, 1994).

130. Vesselin Dimitrov, Bulgaria: The Uneven Transition (London, 2001).

I 3 I. Aleksander Petkov (ed.), Bălgarskoto sindikalno dviženie - minalo i nastojašte [The TradeUnion Movement in Bulgaria - Past and Present] (Sofia, 2000).

I32. On this, see the study cited in n. I34. 
the "lifeworld", ${ }^{33}$ and from this perspective they contribute significantly to our knowledge of the modes of living and the self-conception of Bulgarian workers under state socialism. Noteworthy in this context are articles about Bulgarian workers' perceptions of their own living conditions (on the basis of surveys conducted by the aforementioned tradeunion research institute), ${ }^{134}$ about the social situation in youth construction brigades, ${ }^{\mathrm{I} 35}$ about mental and subcultural structures of everyday work life, ${ }^{136}$ and about workplace networks and clientelism, a subject that has also been investigated in detail for Poland and Czechoslovakia. ${ }^{137}$

Like Romania, the Bulgarian example also suggests the desirability of a comparative investigation of the "peasant-worker" problematic. In the I960s, around 40 per cent of the Bulgarian workforce was recruited from people living in rural conditions. Research by Bulgarian ethnologists has shown that the mass of peasant-workers largely retained their peasant lifestyle and that they were the actual social carriers of egalitarian ideas with regard to wage policy. ${ }^{{ }^{3} 8}$ Research in other countries has presumed, in contrast, that the preference for an egalitarian wage policy is more typical of unskilled labourers, the group usually favoured by communist parties, which cannot be conflated with peasant-workers. ${ }^{\mathrm{I} 9}$

\section{FEDERAL REPUBLIC OF GERMANY}

In investigating the history of the GDR, researchers addressed a broad array of social-historical issues early on. ${ }^{40}$ It may appear problematic to

I33. Ulf Brunnbauer and Karl Kaser (eds), Vom Nutzen der Verwandten. Soziale Netzwerke in Bulgarien (I9. und 20. Jabrbundert) (Vienna, 200I).

I 34. Petăr Petrov, "Lebenszufriedenheit bulgarischer Arbeitnehmer: Aussagen aus den r $980 e r$ Jahren und heutiges Erinnern", in Klaus Roth (ed.), Arbeitswelt - Lebenswelt. Facetten einer spannungsreichen Beziehung im östlichen Europa (Münster [etc.], 2006), pp. 5I-6I.

I 35. Radost Ivanova, “'Stroim za narodnata republika'. Mladežki stroitelni brigadi - škola za komunističesko văzpitanie” ["We're Building for the People's Republic”. The Youth Construction Brigades - A School of Communist Education], in Radost Ivanova et al. (eds), Socializmăt - realnost i iljuzii. Etnologični aspekti na vsekidnevnata kultura [Socialism - Reality and Illusions. Ethnological Aspects of Everyday Culture] (Sofia, 2003), pp. 54-62.

I36. Milena Benovska-Săbkova, "Pir vo vreme na rabota: vsekidnevni socialističeski praktiki" [Feasting During Working Hours - Everyday Socialist Practices], Mif, 8 (2003), pp. I45-1 53. 137. Idem, "Social Networks, Coalitions and Clientelism at the Workplace in the Period 1960-1989 in Sofia”, in Klaus Roth (ed.), Arbeit im Sozialismus - Arbeit im Postsozialismus. Erkundungen der Arbeitswelt im östlichen Europa (Münster [etc.], 2004), pp. I09-I 27.

I38. Juljan Konstantinov, "Nahrung vom Dorf, Beziehungen durch die Stadt. Über den gegenwärtigen Charakter des bulgarischen Land-Stadt-Haushalts", in Vom Nutzen der Verwandten, pp. 43-67.

I39. On this, see the studies cited in n. $3 \mathrm{I}$.

I 40. Five years after the collapse of the GDR, the first larger review of social-historical research on the GDR indicated the breadth of issues that had been examined here. See Hartmut Kaelble, Jürgen Kocka, and Hartmut Zwahr (eds), Sozialgeschichte der DDR, (Stuttgart, 1994). 
separate working-class history from these investigations, especially since the most fruitful social-historical research strategies focus methodologically and conceptually on overarching social developments. ${ }^{\text {III }}$ On the other hand, the "workplace" as a system has assumed a central position in those studies that, in examining the causes of the GDR's collapse, have concentrated on the tendeny to informal "socialization of the state". ${ }^{42}$ Investigations of everyday workplace life in the GDR indicate that places of work were embedded in a network of secondary power and exchange relations beneath the level of formal planning decisions and thus can be understood as the "sediment" from the informal erosion of state structures. ${ }^{143}$

After the information veil surrounding the GDR was lifted with German reunification, concepts were developed to compare working-class history in the GDR with that in the Federal Republic, especially with regard to traditions of working-class milieu. ${ }^{\mathrm{I} 44}$ In addition to the possibility of using now accessible archival sources, studies of oral history also focused on East German working-class milieu. ${ }^{\mathrm{I} 5}$ The question of continuities and ruptures in the social development of the GDR - which is part of the search for the causes of the collapse of the second German state - has proved productive in discussions of working-class milieu. ${ }^{\text {I }}{ }^{46}$

I4I. On this, see the comparison between the GDR and the Federal Republic of Germany conducted on the basis of the categories of social structure in Martin Kohli, "Die DDR als Arbeitsgesellschaft? Arbeit, Lebenslauf und soziale Differenzierung”, in Kaelble, Kocka, and Zwahr, Sozialgeschichte der DDR, pp. 3 I-6I.

I42. Ralph Jessen, "Die Gesellschaft im Staatssozialismus. Probleme einer Sozialgeschichte der DDR", Geschichte und Gesellschaft, 2 I (1995), pp. 96-1 10.

I43. Renate Hürtgen and Thomas Reichel (eds), Der Schein der Stabilität. DDR-Betriebsalltag in der Ära Honecker (Berlin, 200I); Sandrine Kott, Le communisme an quotidien. Les entreprises d'État dans la société est-allemande (Paris, 200I).

I44. Peter Alheit, Hanna Haack, Heinz-Gerd Höfschen, and Renate Meyer-Braun, Gebrochene Modernisierung - Der langsame Wandel proletarischer Milieus. Eine empirische Vergleichsstudie ost- und westdeutscher Arbeitermilieus in den 1950er Jabren, I: Sozialgeschichtliche Rekonstruktionen, II: Soziologische Deutungen (Bremen, 1999); Bernd Faulenbach, Annette Leo, and Klaus Weberskirch, Zweierlei Geschichte. Lebensgeschichte und Geschichtsbewusstsein von Arbeitnehmern in West- und Ostdeutschland (Essen, 2000).

145. Lutz Niethammer, Alexander von Plato, and Dorothee Wierling, Die volkseigene Erfahrung. Eine Archäologie des Lebens in der Industrieprovinz der DDR. 30 biographische Eröffnungen (Berlin, 1991); Dagmar Semmelmann, Schauplatz Stalinstadt/EKO. Erinnerungen an den 17. Juni 1953, I-II (Potsdam, 1993).

I46. See Christoph Kleßmann, "Die Beharrungskraft traditioneller Milieus in der DDR", in Manfred Hettling, Claudia Huerkamp, Paul Nolte, and Hans-Walter Schmuhl (eds), Was ist Gesellschaftsgeschichte? (Munich, I99I), pp. I46-I 54; Horst Groschopp, "Überlegungen zur Kontinuität der deutschen Arbeiterbewegungskultur in der DDR”, in Wolfgang Kaschuba, Gottfried Korf, and Bernd Jürgen Warneken (eds), Arbeiterkultur seit 1945. Ende oder Veränderung (Tübingen, I99I), pp. I23-140; Michael Hofman and Dieter Rink, "Die Auflösung der ostdeutschen Arbeitermilieus. Bewältigungsmuster und Handlungsspielräume ostdeutscher Industriearbeiter im Transformationsprozess", Aus Politik und Zeitgeschichte, 26-27 (1993) pp. 29-36; Michael Hofman, "Die Kohlearbeiter von Espenhain. Zur Enttraditionalisierung eines 
Scholars of workplace history have also benefited from the altered archival situation, as they can now examine how the GDR dealt with the industrial heritage of the Third Reich and how this heritage effected workers' modes of behaviour. ${ }^{\text {I47 }}$

This new beginning, however, was characterized above all by a fundamental critique of "older" working class historiography and its emphasis on the "market situation" of workers and the resulting socio-structural implications, the living conditions, and the milieu of workers. ${ }^{14^{8}}$ More recent historiography has emphasized, in contrast, a "micro-political" approach, that is, the role of workers as workplace actors who possess manoeuvring room in a complex production and social milieu beyond the formal order of the workplace; it has also emphasized, within the scope of the "turn to cultural history", the significance of ties beyond the "class model", for example, the significance of gender, generation, and ethnic affiliation. ${ }^{\text {I9 }}$ These debates have resulted in publications on working-class history of the GDR that expand the analytic frame of working-class history. One such publication is the anthology on the central German chemical industry and its workers in the twentieth century. ${ }^{150}$

Behind these debates are diametrically opposed positions, which necessarily emerged in the course of analysing the working-class history of the GDR on the basis of concepts, questions, and interpretive patterns drawn from West German industrial society. It is difficult, the one side has argued, to transfer concepts such as "class", "stratum", and "social protest" from marketoriented, competitive societies to the state socialist, planned-economic society of the GDR. ${ }^{15 \mathrm{I}}$ The other side counters, on the basis, for instance, of the

ostdeutschen Arbeitermilieus", in Michael Vester, Michael Hofman, and Irene Zierke (eds), Soziale Milieus in Ostdeutschland. Gesellschaftliche Strukturen zwischen Zerfall und Neubildung (Cologne, 1995), pp. 91-I35; idem, "Die Leipziger Metallarbeiter. Etappen sozialer Erfahrungsgeschichte. Milieubiographie eines Arbeitermilieus in Leipzig”, in ibid., pp. I 36-192; Helmut W. Smith, "The Demography of Discontinuity in Bitterfeld, 1930-1953", in Peter Hübner and Klaus Tenfelde (eds), Arbeiter in der SBZ/DDR (Essen, I999), pp. 8 I I-822.

I47. Friederike Sattler, "Zum Konfliktverhalten von Arbeitern in der Chemieindustrie der DDR", in Brenner and Heumos, Sozialgeschichtliche Kommunismusforschung, 35-76.

I48. Thomas Welskopp, "Von der verhinderten Heldengeschichte des Proletariats zur vergleichenden Sozialgeschichte der Arbeiterschaft - Perspektiven der Arbeitergeschichtsschreibung in den I990er Jahren", in 1999. Zeitschrift für Sozialgeschichte des 20. und 21. Jahrbunderts, 3 (1993), pp. 34-57.

I49. Representative of this research concept is Karl Lauschke and Thomas Welskopp (eds), Mikropolitik im Unternehmen. Arbeitsbeziehungen und Machtstrukturen in industriellen Großbetrieben des 20. Jabrhunderts (Essen, 1994).

I 50. Hermann-Josef Rupieper, Friederike Sattler, and Georg Wagner-Kyora (eds), Die mitteldeutsche Chemieindustrie und ibre Arbeiter im 20. Jahrbundert (Halle, 2005).

I I. Dietmar Süß, "Arbeitergeschichte und Organisationssoziologie: Perspektiven einer Annäherung", in ibid., pp. 76-89; on this, see also Christoph Kleßmann, "Die 'verstaatlichte Arbeiterbewegung'. Überlegungen zur Sozialgeschichte der Arbeiterschaft in der DDR”, in 
category of "social protest", with the call to level radically distinctions between "capitalism" and "socialism" in favour of overarching historical research on protest and crowd history. ${ }^{\mathrm{IS2}}$ Initial studies using this latter conception of social protests have already been published. ${ }^{153}$

The example of the worker uprising of 17 June 1953, however, makes clear that using the concepts of a capitalist-critical crowd history to interpret central and politically charged protests cannot hope for broader resonance at this time. Studies of the uprising of I7 June 1953 have been constructed primarily as a history of political events; without empirical comparison to other revolts, they cannot do justice to the claim that this uprising was part of the series of major revolts in German and European history - as was evident everywhere, for example, on the fiftieth anniversary of the uprising. ${ }^{\mathrm{IS4}}$

Karsten Rudolph and Christl Wickert (eds), Geschichte als Möglichkeit. Über die Chancen von Demokratie. Festschrift für Helga Grebing (Essen, 1995), pp. I08-I 19.

I 5 2. On this see the article by Lindenberger cited in n. 9.

I 53. Andrew Port, "When Workers Rumbled: The Wismut Upheaval of August I95 I in East Germany", Social History, 22 (1997), pp. I45-172; Richard Bessel, "The People's Police and the Miners of Saalfeld, August I95', in idem and Clive Emsley (eds), Patterns of Provocation: Police and Public Order (New York, 2000), pp. 63-79.

I 54. From the wealth of literature on the uprising of 17 June 1953, I cite here only: Christoph Buchheim, "Wirtschaftliche Hintergründe des Arbeiteraufstandes vom 17. Juni 1953 in der DDR", Vierteljahrshefte für Zeitgeschichte, 38 (1990) pp. 4I 5-433; Torsten Diedrich, Der 17. Juni 1953 in der DDR. Bewaffnete Gewalt gegen das Volk (Berlin, I99I); Heidi Roth, "Der I7. Juni 1953 im damaligen Bezirk Leipzig. Aus den Akten des PDS-Archivs Leipzig”, Deutschland Archiv, 24 (1991) pp. 573-584; Manfred Hagen, DDR - Juni '53. Die erste Volkserhebung im Stalinismus (Stuttgart, I992); Angelika Klein, Die Arbeiterrevolte im Bezirk Halle, 4 vols (Potsdam, I993); Udo Wengst, "Der Aufstand am 17. Juni 1953 in der DDR. Aus den Stimmungsberichten der Kreis- und Bezirksverbände der Ost-CDU im Juni und Juli 1953", Vierteljabrshefte für Zeitgeschichte, 4I (1993), pp. 277-321; Gerhard Beier, Wir wollen freie Menschen sein. Der 17. Juni 1953: Bauleute gingen voran (Frankfurt/M [etc.], I993); Arnim Mitter (ed.), Der Tag X. Neue Forschungen zur Geschichte des I7. Juni 1953 (Berlin, I994); IlkoSascha Kowalczuk, Arnim Mitter, and Stefan Wolle, Der Tag X-17. Juni 1953. Die "innere" Staatsgründung der DDR als Ergebnis der Krise 1952/54 (Berlin, 1996); Rainer Hildebrandt, Der I7. Juni. Zehn Erlebnisgeschichten von Personen in verschiedenen Brennpunkten des Aufstandes sowie ergänzende dokumentarische Materialien (Berlin, 1997); Olaf Freier, "Der Juni-Aufstand 1953 im Industrierevier Bitterfeld-Wolfen”, Sachsen-Anhalt. Beiträge zur Landesgeschichte, I I (1998), pp. 36-75; Heidi Roth, Der 17. Juni 1953 in Sachsen (Cologne, 1999); Christoph Kleßmann and Bernd Stöver (eds), 1953 - Krisenjabr des Kalten Krieges in Europa. Neue Forschungen (Cologne [etc.], 1999); Christian Ostermann (ed.), Uprising in East Germany 1953: The Cold War, the German Question, and the First Major Upheaval behind the Iron Curtain (Budapest, 200I); Hermann-Josef Rupieper (ed.), “...und das Wichtigste ist doch die Einheit”: Der 17. Juni 1953 in den Bezirken Halle und Magdeburg (Münster [etc.], 2003); Friederike Sattler, "'Seht euch vor, ihr sitzt auf einem Vulkan'. Der I7. Juni 1953 in den Leunaund Bunawerken", in ibid., pp. 280-329; Helke Stadtland, "Arbeiter im Streik gegen 'ihre' Gewerkschaften. Der Freie Deutsche Gewerkschaftsbund (FDGB) vor und nach dem Aufstand des 17. Juni 1953", Gewerkschaftliche Monatshefte, 54 (2003), pp. 360-369; Heike Schmidt, Der I7. Juni I953 in Rostock (Berlin, 2003); Ilko-Sascha Kowalczuk, I7. Juni 1953 - Volksaufstand in der DDR. Ursachen, Abläufe, Folgen (Bremen, 2003). 
Incidentally, researchers of the conflict behaviour of workers in the GDR have been unimpressed by the burdens of political tribute with regard to 17 June. Their central argument here has been that workers did not regard massive confrontations with the party and state apparatus as advisable after 1953. The SED's strategy of social pacification, encircling firms and factories with the Stasi apparatus over the course of the I960s, the activities of the conflict commissions formed in 1953, and the tacit truce between state and workforce on the issues of wages and norms ultimately resulted in the state itself setting the rules for workplace conflict behaviour after the traumatic experience of $1953 .{ }^{155}$ Research on the group and conflict behaviour of women, ${ }^{156}$ and long-term studies of the mental structures and the social modes of behaviour of the industrial

I55. Benno Sarel, Arbeiter gegen den 'Kommunismus'. Zur Geschichte des proletarischen Widerstandes in der DDR (1945-1958), 2nd edn (Göttingen [etc.], 1991); Peter Hübner, Konsens, Konflikt und Kompromiss. Soziale Arbeiterinteressen und Sozialpolitik in der SBZ/DDR 1945-1970 (Berlin, I995); idem, "Arbeitskonflikte in Industriebetrieben der DDR nach 1953", in Ulrike Poppe, Rainer Eckert, and Ilko-Sascha Kowalczuk (eds), Zwischen Selbstbehauptung und Anpassung. Formen des Widerstandes und der Opposition in der DDR (Berlin, I995), pp. I78-I9I; idem, "Identitätsmuster und Konfliktverhalten der Industriearbeiterschaft der SBZ/ DDR", Bohemia, 42 (200I), pp. 220-243; idem, "Arbeitskampf im Konsensgewand? Zum Konfliktverhalten von Arbeitern im 'realen' Sozialismus”, in Bispinck, Danyel, Hertle, and Wentker, Aufstände im Ostblock, pp. I95-2 I3; Georg Wagner-Kyora, "Arbeiter verhandeln? Betriebsalltag, Konfliktverhalten und Mentalität von Chemiearbeitern in den Leuna-und den Bunawerken 1949-1989. Ein Projekt zur Erforschung der Arbeitergeschichte des Landes Sachsen-Anhalt," Hallische Beiträge zur Zeitgeschichte, Io (200I), pp. I I9-I37; Renate Hürtgen, “ “... wir wussten schon, dass die im Betrieb waren, nur nicht, wer nun wirklich dabei war'. Operative Personenkontrolle des MfS im DDR-Betrieb", Deutschland Archiv, 36 (2003), pp. 34-44; Peter Alheit and Hanna Haack, Die vergessene "Autonomie" der Arbeiter. Eine Studie zum frühen Scheitern der DDR am Beispiel der Neptunwerft (Berlin, 2004); Renate Hürtgen, "Der DDR-Betrieb als konflikt- und herrschaftsfreie Zone? Zum Konfliktverhalten von Arbeitern in den siebziger und achtziger Jahren," in Rupieper, Sattler, and Wagner-Kyora, Die mitteldeutsche Chemieindustrie, pp. 259-286; idem, "Konfliktverhalten der DDR-Arbeiterschaft und Staatsrepression im Wandel”, in Hübner, Kleßmann, and Tenfelde, Arbeiter im Staatssozialimus, pp. 383-403; Helke Stadtland, "Konfliktlagen und Konfliktformen. Arbeiter in der DDR zwischen Integration, Disziplinierung und Verweigerung”, in ibid., pp. 357-381; Michael Hofman, “'Solidarität mit Prag'. Arbeiterproteste 1968 in der DDR”, in Gehrke and Horn, 1968 und die Arbeiter, pp. 92-102.

I 56. Sabine Gensior, "Die Bedeutung von Gruppenstrukturen und sozialer Bindung. Frauenerwerbstätigkeit in ostdeutschen Betrieben", in Martin Heidenreich (ed.), Krisen, Kader, Kombinate. Kontinuität und Wandel in ostdeutschen Betrieben (Berlin, I992), pp. 273-28 I; Angelika Behnke and Ruth Westerwelle, Die Franen von ORWO. I3 Lebensbilder (Leipzig, I995); Francesca Weil, Herrschaftsalltag und soziale Wirklichkeit. Zwei sächsische Betriebe in der DDR während der Honecker-Ära (Cologne, 2000); Annegret Schüle, "Die Spinne". Die Erfabrungsgeschichte weiblicher Industriearbeit im VEB Leipziger Baumwollspinnerei (Leipzig, 200I); Francesca Weil, "Betriebliches Sozialverhalten von Frauen im Spannungsfeld von staatlich postulierter Emanzipation, Alltag und persönlichen Lebensansprüchen in der späten DDR. Zwei Fallbeispiele aus der chemisch-pharmazeutischen Industrie”, in Rupieper, Sattler, and Wagner-Kyora, Die mitteldeutsche Chemieindustrie, pp. 287-3 г 2. 
workforce ${ }^{157}$ (in addition to milieu studies), as well as studies on the selfconception of workers from a generational-historical perspective ${ }^{158}$ have supplemented and differentiated this model.

Research on industrial work behaviour ${ }^{159}$ and work organization ${ }^{160}$ have illuminated primarily the areas of friction between the planning system and the "production culture" of workers based on life-world value orientations. These investigations are less informative about manifest conflicts than about the structural abrasion of the SED's industrial policies. In addition to the role of plant management in work conflicts, ${ }^{161}$ conflict (and cooperation) between the SED factory groups and workplace personnel have also been investigated for the Soviet occupation zone, ${ }^{162}$, three major industrial firms from 1959 to $1965,{ }^{163}$ and the state

I 57. Peter Alheit and Dietrich Mühlberg, Arbeiterleben in den I95oer Jabren. Konzeption einer mentalitätsgeschichtlichen Vergleichsstudie biografischer Verläufe in Arbeitermilieus der Bundesrepublik Deutschland und der DDR (Bremen, 1990); Peter Hübner, "Die Zukunft war gestern: Soziale und mentale Trends in der DDR-Industriearbeiterschaft”, in Kaelble, Kocka, and Zwahr, Sozialgeschichte der DDR, pp. I7I-187.

I58. Georg Wagner-Kyora, "Wenn man die Ohren in der Masse aufmacht und in ihr Bewusstsein blickt...'. Fragen nach dem Selbstverständnis von Generationen in IM-Berichten über die Karbidarbeiter der Buna-Werke in Schkopau”, in Rupieper, Sattler, and Wagner-Kyora, Die mitteldentsche Chemieindustrie, pp. 341-377.

I 59. Alf Lüdtke, “'Helden der Arbeit' - Mühen beim Arbeiten. Zur missmutigen Loyalität von Industriearbeitern in der DDR", in Kaelble, Kocka, and Zwahr, Sozialgeschichte der DDR, pp. I $88-213$.

I60. Richard Rottenburg, “'Der Sozialismus braucht den ganzen Menschen'. Zum Verhältnis vertraglicher und nichtvertraglicher Beziehungen in einem VEB”, Zeitschrift für Soziologie, 20 (1991), pp. 305-320; Jörg Roesler, "Die Produktionsbrigaden in der DDR. Zentrum der Arbeitswelt?", in Kaelble, Kocka, and Zwahr, Sozialgeschichte der DDR, pp. I44-170; Peter Hübner, “Sozialistischer Fordismus?” Oder: Unerwartete Ergebnisse eines Kopiervorganges. Zur Geschichte der Produktionsbrigaden in der DDR”, in Alf Lüdtke et al. (eds), Amerikanisierung: Traum und Alptraum im Deutschland des 20. Jabrbunderts (Stuttgart, 1996), pp. 96-I I 5; Jörg Roesler, "Probleme des Brigadealltags. Arbeitsverhältnisse und Arbeitsklima in volkseigenen Betrieben 1950-1989", Aus Politik und Zeitgeschichte, 38 (1997), pp. 3-17; Thomas Reichel, “'Jugoslawische Verhältnisse?' - Die 'Brigaden der sozialistischen Arbeit' und die 'Syndikalismus-Affäre' (1959-1962)", in Thomas Lindenberger (ed.), Herrschaft und Eigensinn in der Diktatur. Studien zur Gesellschaftsgeschichte der DDR (Cologne [etc.], I999), pp. $45-73$.

16r. Peter Hübner, "Um Kopf und Kragen. Zur Geschichte der innerbetrieblichen Hierarchien im Konstituierungsprozess der DDR-Gesellschaft", Mitteilungen aus der Kulturwissenschaftlichen Forschung, 16:33 (1993), pp. 210-232; idem, "Durch Planung zur Improvisation. Zur Geschichte des Leitungspersonals in der staatlichen Industrie der DDR", Archiv für Sozialgeschichte, 39 (1999), pp. 197-233.

162. Thomas Reichel, “Feste Burgen der Partei?” Aufbau und Rolle der SED-Betriebsgruppen in der Sowjetischen Besatzungszone (SBZ) 1946-1949”, Internationale Wissenschaftliche Korrespondenz zur Geschichte der deutschen Arbeiterbewegung, 36 (2000), pp. 62-99.

163. Christoph Vietzke, Konfrontation und Kooperation. Funktionäre und Arbeiter in Großbetrieben der DDR vor und nach dem Mauerbau (Essen, 2008). 
of Brandenburg from 1945 to $1952 .{ }^{164}$ Two publications stand out on research about trade-union and worker relations, one that focuses on the "founding years" of GDR trade unions, ${ }^{165}$ the other on the activities of union workplace representatives from the Free German Trade Union Federation (Freier Deutscher Gewerkschaftsbund). ${ }^{166}$ Using a broad base of sources, the cultural work of trade unions at the workplace ${ }^{167}$ has also been analysed as one dimension of the research field "workforce and culture". ${ }^{168}$

Social-historical and social-political longitudinal studies addressing comprehensive issues have been helpful in better localizing the workforce within GDR society. ${ }^{169}$ An introduction to the most recent research on the subject

I64. Friederike Sattler, Wirtschaftsordnung im Übergang: Politik, Organisation und Funktion der KPD/SED im Land Brandenburg bei der Etablierung der zentralen Planwirtschaft der $S B Z / D D R$ 1945-I952, 2 vols (Münster [etc.], 2002).

165. Helke Stadtland, Herrschaft nach Plan und Macht der Gewohnheit. Sozialgeschichte der Gewerkschaften in der SBZ/DDR 1945-1953 (Essen, 200I).

166. Renate Hürtgen, Zwischen Disziplinierung und Partizipation. Vertranensleute des FDGB im DDR-Betrieb (Cologne [etc.], 2005).

I67. Sandrine Kott, "Zur Geschichte des kulturellen Lebens in DDR-Betrieben. Konzepte und Praxis der betrieblichen Kulturarbeit", Archiv für Sozialgeschichte, 39 (1999), pp. 167-195; Helke Stadtland, "Kommunismus und Kultur. Überlegungen zur betrieblichen Kulturarbeit der staatssozialistischen Gewerkschaften Osteuropas und der DDR", in Brenner and Heumos, Sozialgeschichtliche Kommunismusforschung, pp. 205-242; Annette Schuhmann, "Kulturhäuser der Gewerkschaften in Industriebetrieben der DDR der fünfziger Jahre”, in ibid., pp. 277-303; idem, "'Macht die Betriebe zu Zentren der Kulturarbeit'. Gewerkschaftlich organisierte Kulturarbeit in den Industriebetrieben der DDR in den fünfziger Jahren: Sozialhistorisches Novum oder Modifizierung betriebspolitischer Traditionen?”, in Hübner, Kleßmann, and Tenfelde, Arbeiter im Staatssozialismus, pp. 271-289; idem, Kulturarbeit im sozialistischen Betrieb. Gewerkschaftliche Erziehungspraxis in der SBZ/DDR 1946-1970 (Cologne [etc.], 2006).

I68. Dietrich Mühlberg, "Warum sollten wir wissen, was Arbeiter sind und was sie in der Freizeit machen? Zur Bestimmung von Arbeiterkultur in der DDR”, in Wolfgang Kaschuba, Gottfried Korf, and Bernd Jürgen Warneken (eds), Arbeiterkultur seit 1945 - Ende oder Veränderung? (Tübingen, I99I), pp. 7I-84; Horst Groschopp, "Überlegungen zur Kontinuität der deutschen Arbeiterbewegungskultur in der DDR", in ibid., pp. I23-I40; Dietrich Mühlberg, "Überlegungen zu einer Kulturgeschichte der DDR", in Kaelble, Kocka, and Zwahr, Sozialgeschichte der DDR, pp. 62-94; Simone Barck, “'Ankunft im Real-Sozialismus' anno 1970. Anmerkungen zu sozialen Irritationen und kulturellen Diffusionen am Beispiel der Bewegung schreibender Arbeiter (BSA) in der DDR", Potsdamer Bulletin für zeithistorische Studien, 28/29 (2003), pp. 60-72; idem and Dietrich Mühlberg, "Arbeiter-Bilder und Klasseninszenierung in der DDR. Zur Geschichte einer ambivalenten Beziehung”, in Hübner, Kleßmann, and Tenfelde, Arbeiter im Staatssozialismus, pp. 163-189.

I69. Marc Szydlik, "Arbeitseinkommen und Arbeitsstrukturen. Eine Analyse für die Bundesrepublik Deutschland und die Deutsche Demokratische Republik", Kölner Zeitschrift für Soziologie und Sozialpsychologie, 44 (1992), pp. 292-314; Heike Solga, Auf dem Weg in die klassenlose Gesellschaft? Klassenlagen und Mobilität zwischen Generationen in der DDR (Berlin, 1995); Ralph Jessen, Die Grenzen der Diktatur. Staat und Gesellschaft in der DDR (Göttingen, 1996); Wolfgang Engler, Die Ostdeutschen. Kunde von einem verlorenen Land (Berlin, 1999); Konrad Jarausch, "Care and Coercion: The GDR as Welfare Dictatorship", in idem (ed.), Dictatorship as Experience: Towards a Sociocultural History of the GDR (New York, 1999), pp. 47-69; Beatrix Bouvier, Die DDR - ein Sozialstaat? Sozialpolitik in der Ära Honecker (Bonn, 2002). 
is provided by an investigation that ties together the broad spectrum of approaches to working-class history in the GDR according to central issues. ${ }^{170}$ Finally, there have also been studies that take relations in the GDR as a starting point and outline a comparative working-class history in eastern Europe - in full awareness of the variations in current research within the different countries. These studies either concentrate on variants of workingclass milieu and investigate how the imperatives of the state-socialist system were appropriated within these milieus, ${ }^{17 \mathrm{I}}$ or they delineate different paths of state-socialist development tied to the long-term social development trends of the workforce and of society overall. ${ }^{172}$ The two approaches elucidate "types of decline" for state socialism, each of which tells us something about the forms of transition to post-communist relations.

\section{SUMMARIZING COMMENTS}

Investigating "workers in state socialism" may appear today merely to be retrospection on an obsolete social formation from the history of the twentieth century, "without recognizable contemporary relevance". ${ }^{173}$ This all the more so when the industrial working class as a type, in the traditional configuration that constituted the basis for communist parties in both ideological and practical-political terms, is a historically outdated phenomenon. There is thus a certain consistency in the fact that in discussions about the causes of the collapse of state socialism - insofar as these address the role of workers - the predominiant view is that the workforce produced no structural elements that could be used after the collapse of real socialism for the transformation to a market society.

For instance, the concept of communist neo-traditionalism, which focuses on the networks, patron-client relations, and personally and instrumentally based subsystems in state socialist societies, ${ }^{174}$ moves these informal relations into the proximity of corruption and criminality, ${ }^{175}$ and thereby characterizes the informal power positions of workers in factories

170. Christoph Kleßmann, Arbeiter im “Arbeiterstaat” DDR. Deutsche Traditionen, sowjetisches Modell, westdeutsches Magnetfeld I945-I97I (Bonn, 2007).

I7 I. Christoph Boyer, "Arbeiter im Staatssozialismus: Ein Leitfaden in theoretischer Absicht", Bohemia, 42 (200I), pp. 209-219.

172. Idem, "Sozialgeschichte der Arbeiterschaft und staatssozialistische Entwicklungspfade: konzeptionelle Überlegungen und eine Erklärungsskizze”, in Hübner, Kleßmann, and Tenfelde, Arbeiter im Staatssozialismus, pp. 7I-86.

173. This is the argument of the editor in the introduction to Hübner, Kleßmann, and Tenfelde, Arbeiter im Staatssozialismus.

174. For the GDR, see Karl Ettrich, "Neotraditionalistischer Staatssozialismus. Zur Diskussion eines Forschungskonzepts”, PROKLA, 22:86 (1992), pp. 98-1 I4.

175. Martin Diewald, Informelle Beziehungen und Hilfeleistungen in der DDR: Persönliche Bindungen und instrumentelle Nützlichkeit. Projekt "Lebensverläufe und historischer Wandel in der ehemaligen DDR", Arbeitsbericht 4 (Berlin, 1993). 
and firms in all state socialist countries as a structural attribute incapable of contributing in any productive way to the establishment of a modern social order. Other authors, in contrast, see these networks as a modern socialization form and an important resource in the transition to market society. ${ }^{176}$ It is likely, however, that modernization theory will discover in the state socialist workforce few, if any, structural elements that could be used for the transformation to a market-based order. ${ }^{177}$ This evaluation appears all the more plausible in light of observations here and there of the retreat of the workforce to its old "strongholds", for example, in the Soviet Union comparative studies for the countries of eastern-central and south-eastern Europe are lacking - where, after the establishment of the market, the workforce began to seal itself off in its traditional social-moral and sociocultural values and workplace communicative networks. ${ }^{178}$

If we take up the recommendation made most recently in the debate about new conceptualizations of working-class history and advocate (re-)writing the history of the working class from the perspective of its contributions to civil society, ${ }^{179}$ a different picture emerges, one that offers less occasion for scepticism. Two arguments are immediately evident. First, resistance, dissent, demonstrations, and revolts by workers - not only in Poland, but also in other countries - have consciously sought out the public sphere, thereby strengthening the autonomous public spheres that crystallized around nonstate opinion-forming associations (civil initiatives, cultural associations, debate clubs, etc.). ${ }^{180}$ Second, the massive resistance of workers to socialist labour initiatives (peak load and Stakhanov work, socialist competition) had less to do with the refusal to work than with a rebellion against the workworld impinging on the life-world. In order to increase production, teachers were instructed to call upon pupils to encourage their fathers to greater dedication in socialist competitions. ${ }^{18 \mathrm{r}}$

I76. On this, see the contribution cited in $\mathrm{n}$. I4I.

177. On this in the GDR, see Ulrich Voskamp and Volker Wittke, "Fordismus in einem Land" Das Produktionsmodell der DDR”, Sozialwissenschaftliche Informationen, I9 (1990), pp. 170-180. 178. Vjačeslav Popkov, “Alltagskommunikation in 'zivilen' und 'geschlossenen' Betrieben der Sowjetunion. Ein Vergleich", in Roth, Arbeitswelt - Lebenswelt, pp. 43-49.

179. Jürgen Kocka, "New Trends in Labour Movement Historiography: A German Perspective", International Review of Social History, 42 (1997), pp. 67-78.

I 80. While research on strikes in state socialist countries has primarily emphasized the elementary character of the strike and understood them as simple reflexes to economic stimuli, much evidence can be found on closer inspection that, for instance, the time of the labour disputes was consciously chosen with a view to the greatest possible public sphere. An illustrative example of this is the strike in the Prague coal depots in the summer of 1955, which strike organizers allowed to take place only after the Spartakiad had begun in the state capital. See Heumos, "Zum industriellen Konflikt", p. 489.

I 8 I. Peter Heumos, "Zum Verhalten von Arbeitern in industriellen Konflikten. Tschechoslowakei und DDR im Vergleich”, in Engelmann, Großbölting, and Wentker, Kommunismus in der Krise, pp. $409-427$. 
It is an irony of history that this separation of life-world and work-world has today once again become topical. While scholars of communism begin to agree that one of the most important reasons for the collapse of state socialism was inadequate functional differentiation (and this includes the differentiation of work-world and life-world in the sense of productive and reproductive spheres), ${ }^{\mathrm{I} 2}$ behind their backs post-Fordism abolishes this same differentiation. In the production model of global turbo-capitalism, the dissolution of the boundaries between the work-world and the life-world is continued, with the life-world increasingly being claimed as a resource for the work-world. ${ }^{183}$ Theorists of civil society discuss this development as the "colonizing encroachments of system imperatives on areas of the lifeworld". ${ }^{184}$

I82. M. Rainer Lepsius, "Die Institutionenordnung als Rahmenbedingung der Sozialgeschichte der DDR", in Kaelble, Kocka, and Zwahr, Sozialgeschichte der DDR, pp. I7-30; Ralph Jessen, "Die Gesellschaft im Staatssozialismus. Probleme einer Sozialgeschichte der DDR", Geschichte und Gesellschaft, 2 I (1995), pp. 96-I Io.

183. From the wealth of literature on this issue I mention here only Birgit Huber, "Entgrenzung von Arbeit und Leben im Postfordismus und (Post-)Sozialismus. Subjektivierung als Ansatz für vergleichende Forschung", in Roth, Arbeitswelt - Lebenswelt, pp. I 2 I-I 40.

I 84. Jürgen Habermas, "Further Reflections on the Public Sphere", in Craig Calhoune (ed.), Habermas and the Public Sphere (Cambridge, MA, I994), pp. 42 I-46I, 444. 